\title{
Erlebnis, Empowerment, Beteiligung und Innovation: Die neue Öffentliche Bibliothek
}

Jochumsen, Henrik; Skot-Hansen, Dorte; Rasmussen, Casper Hvenegaard

Published in:

Formierungen von Wissensräumen

Publication date:

2014

Document version

Tidlig version også kaldet pre-print

Citation for published version (APA):

Jochumsen, H., Skot-Hansen, D., \& Rasmussen, C. H. (2014). Erlebnis, Empowerment, Beteiligung und Innovation: Die neue Öffentliche Bibliothek. In O. Eigenbreodt, \& R. Stang (Eds.), Formierungen von Wissensräumen: Optionen des Zugangs zu Information und Bildung (pp. 67-80). De Gruyter. Age of Access? Grundfragen der Informationsgesellschaft http://www.degruyter.com/viewbooktoc/product/203967 

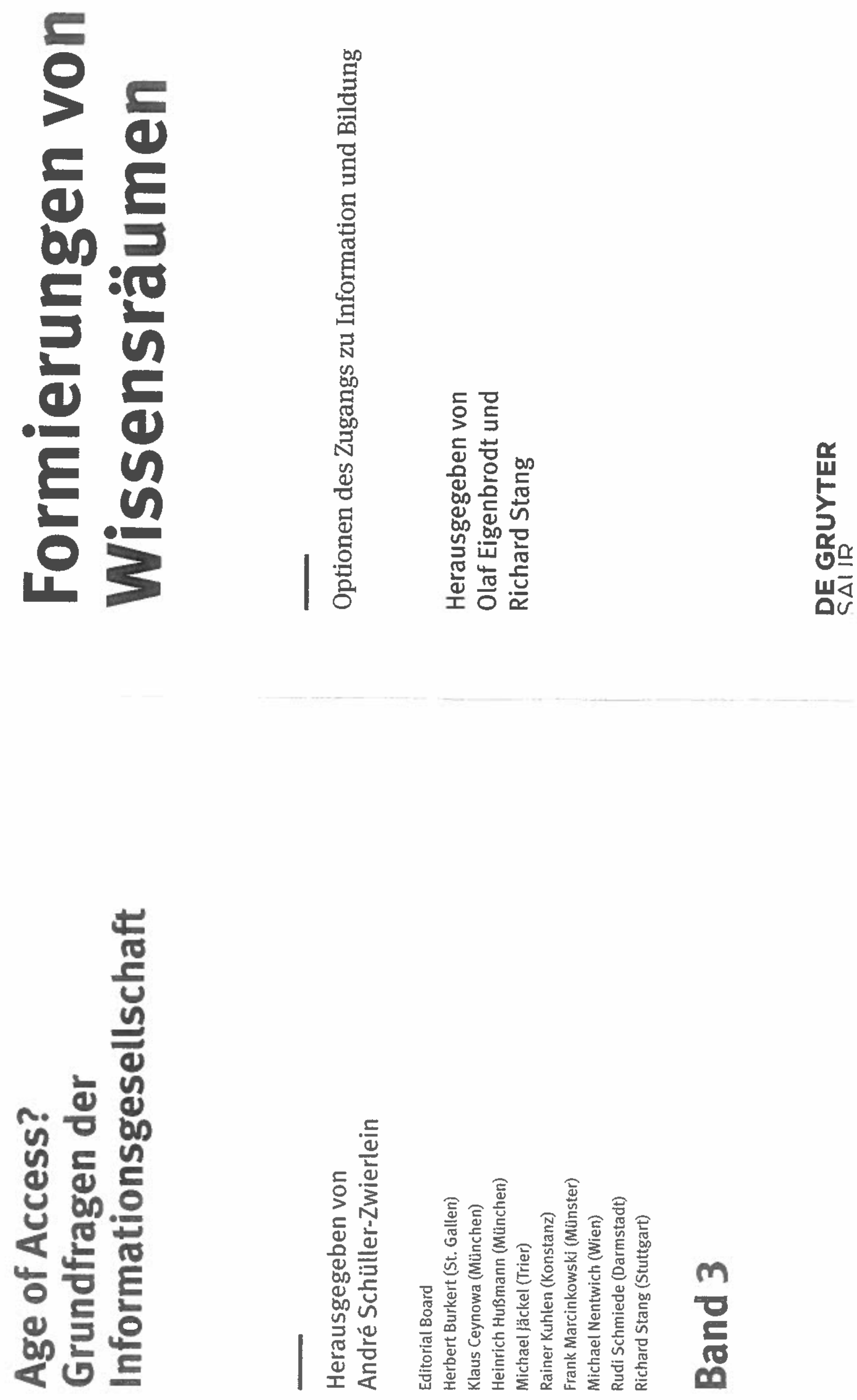


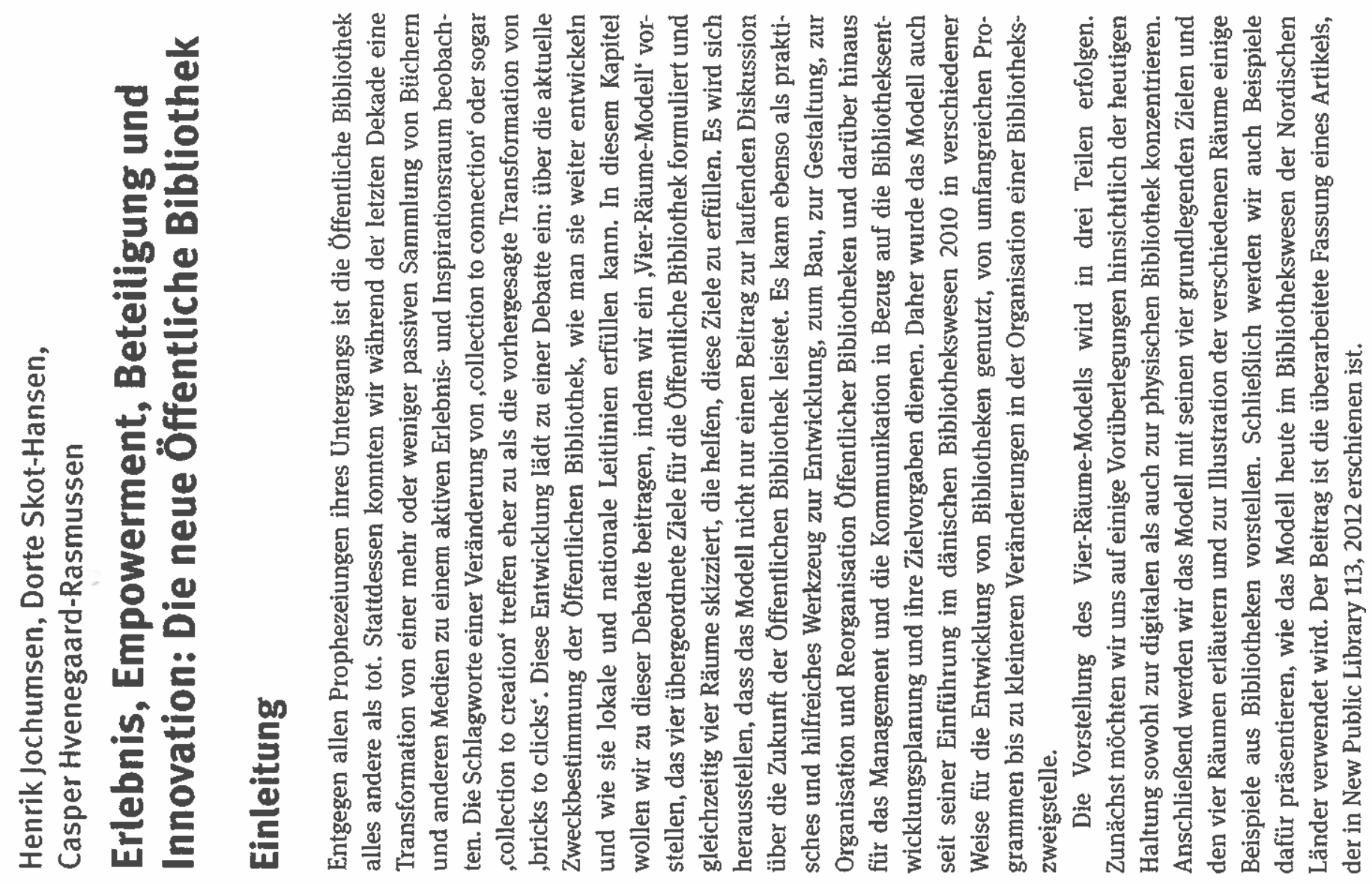


8

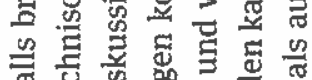

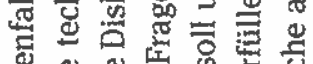

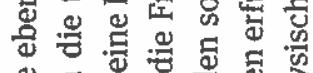

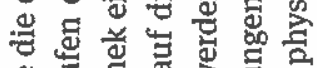
ऊँ

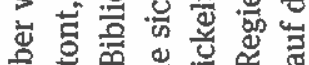

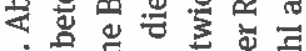
齐 on 自专 는 过:

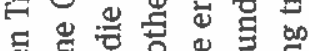

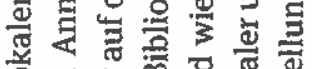
응. 可

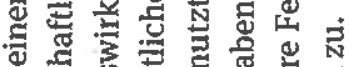

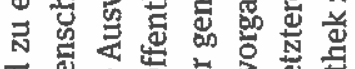

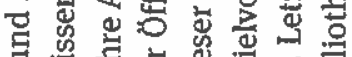

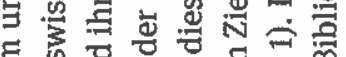

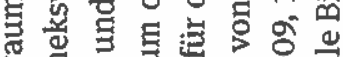
政 象象 3

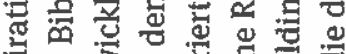
政

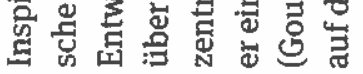

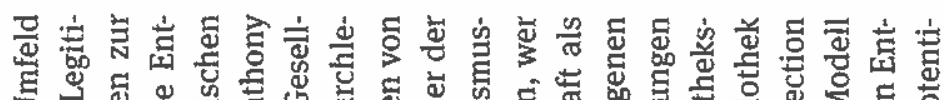

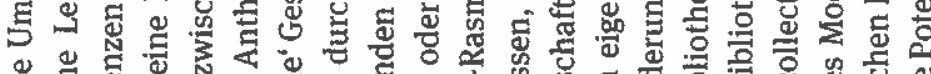

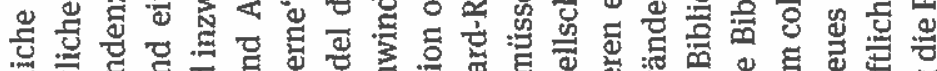

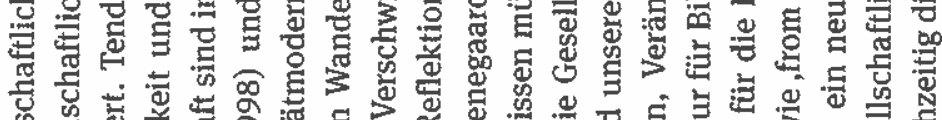

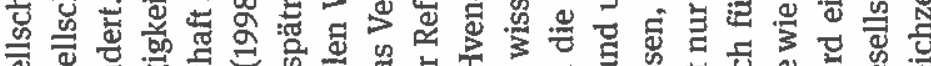

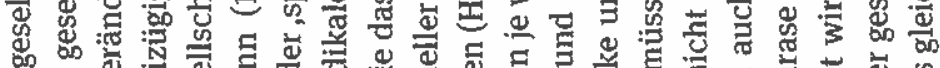

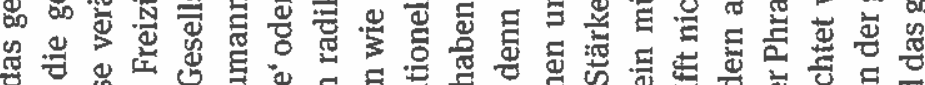

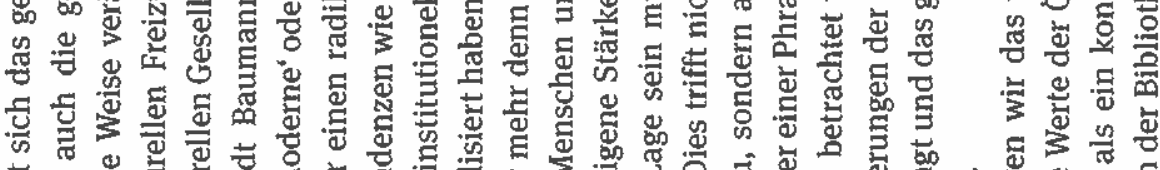

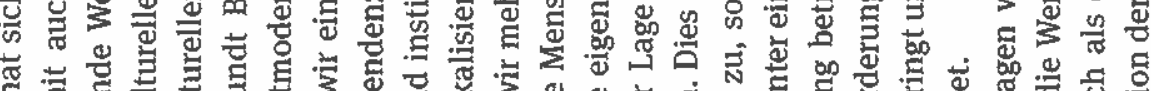

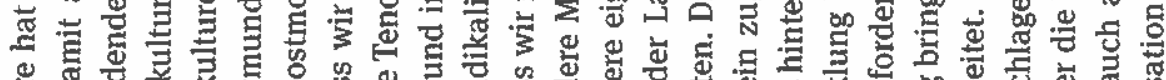

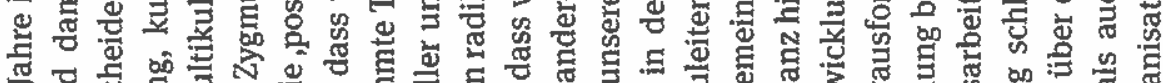

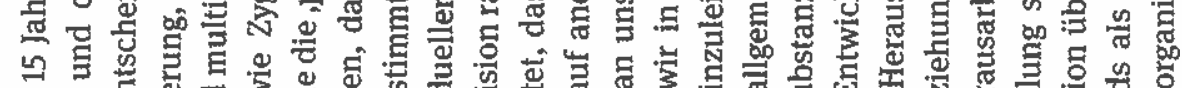

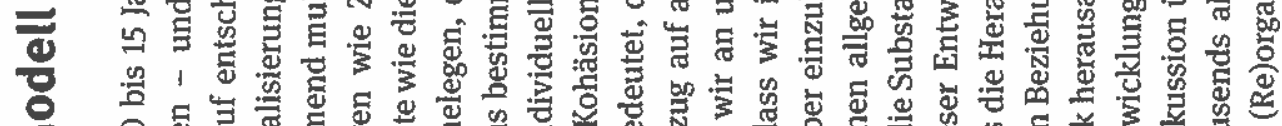
它

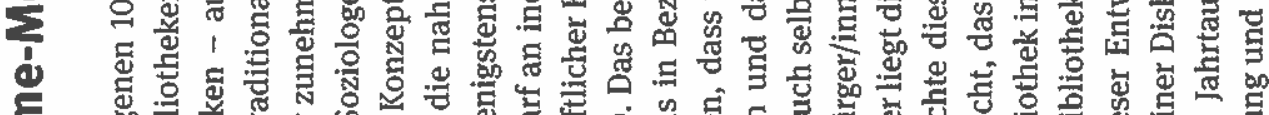

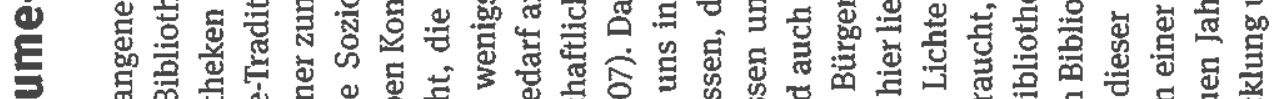

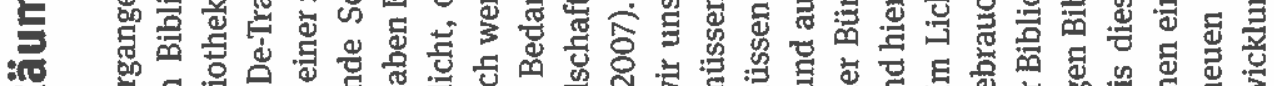

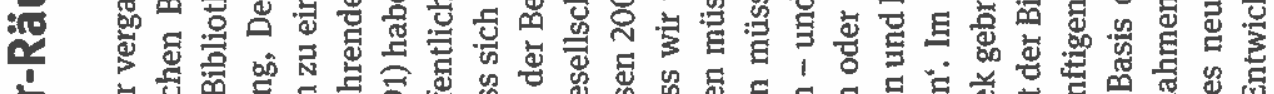

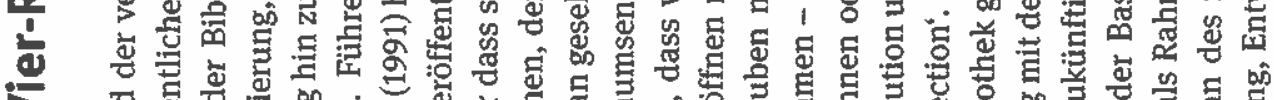

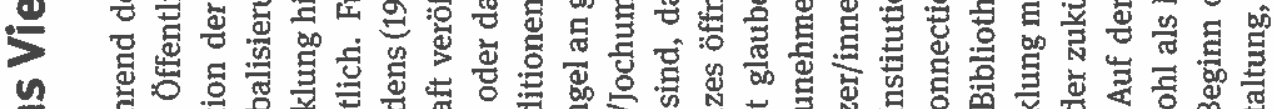

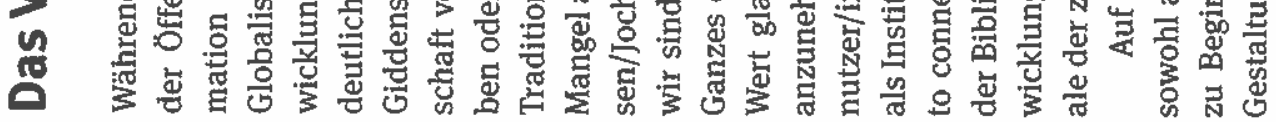

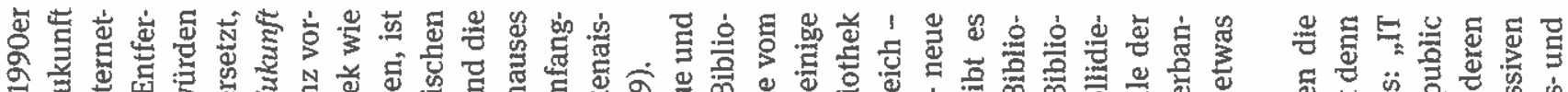

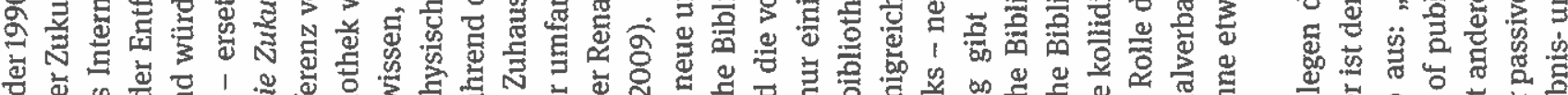

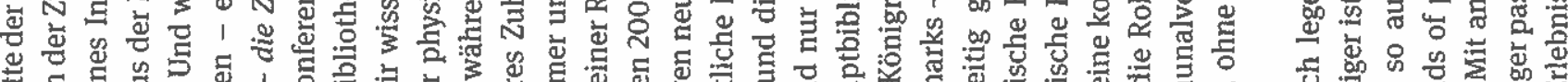

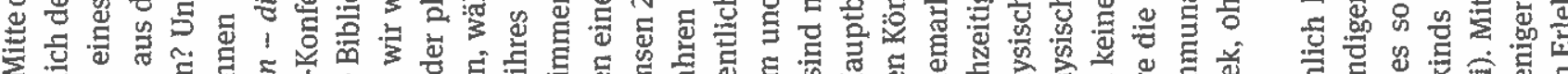

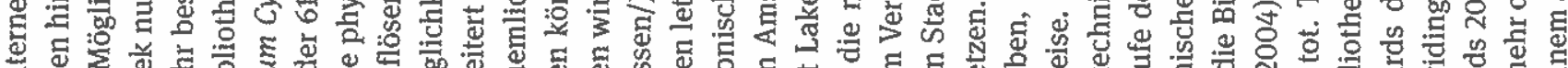

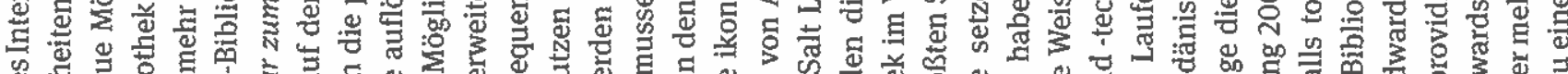

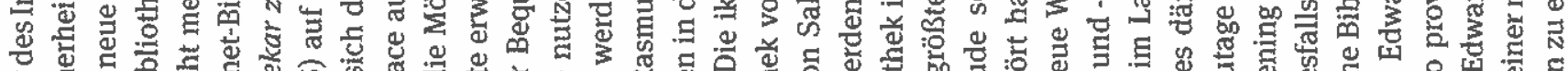

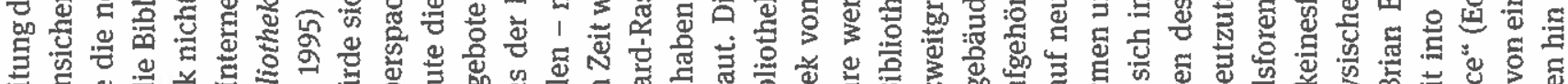

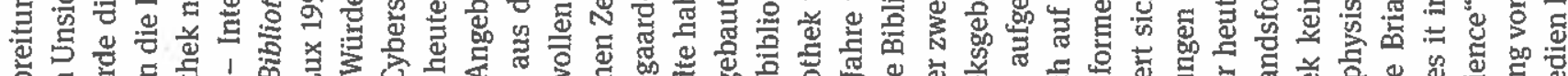

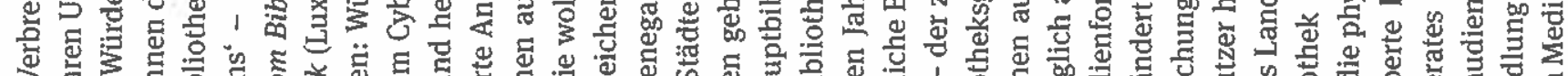

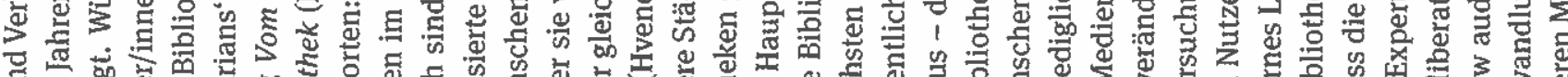

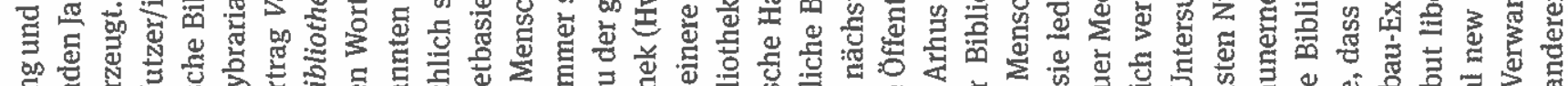

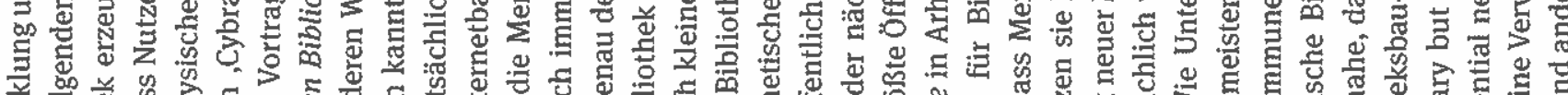

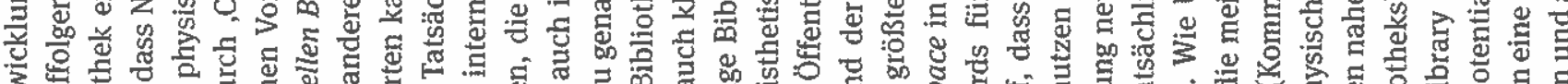

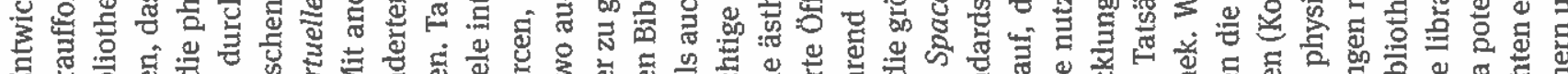

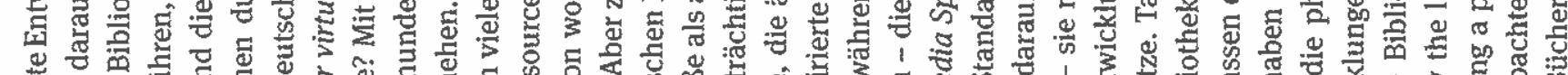

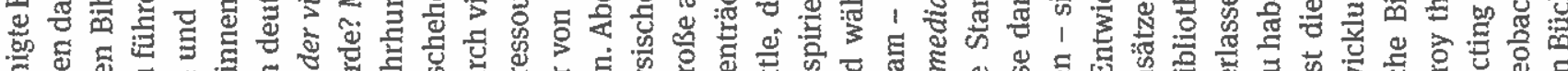

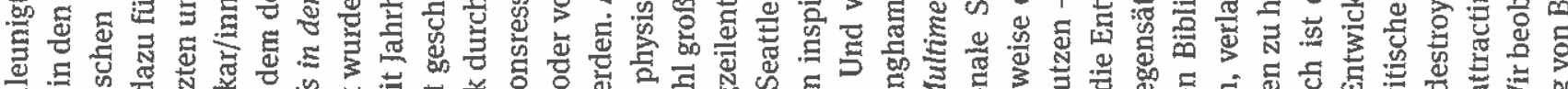

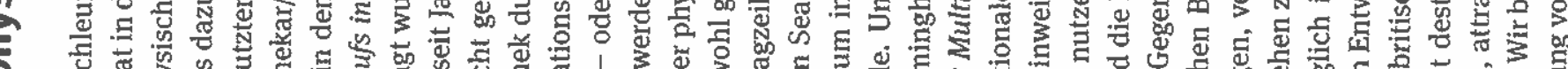

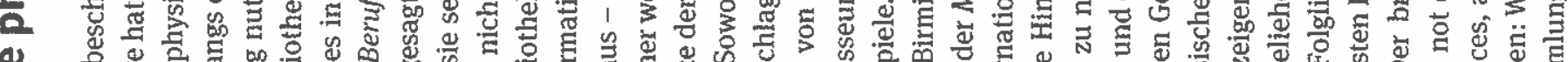

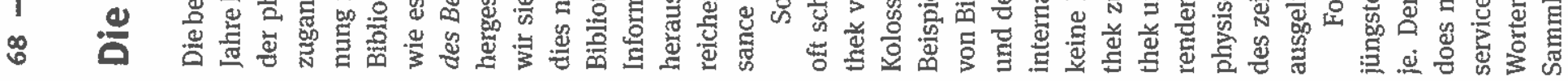




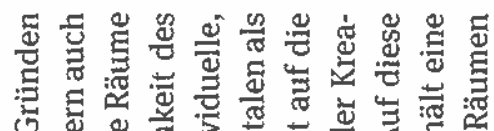

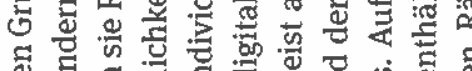

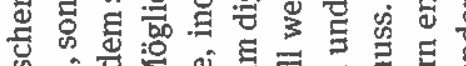

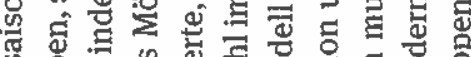

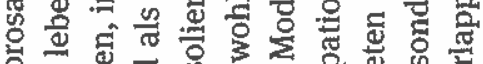

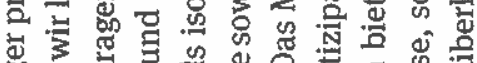

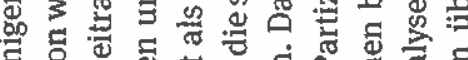

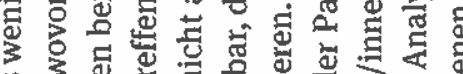

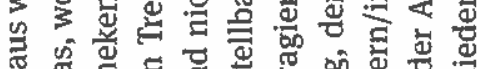

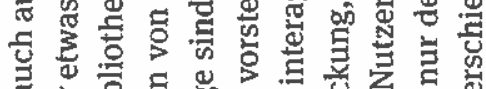

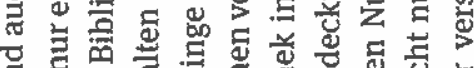

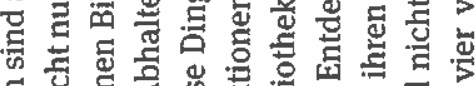

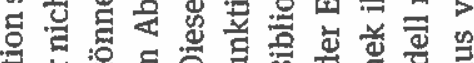

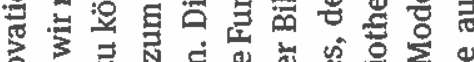

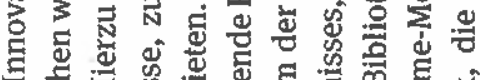

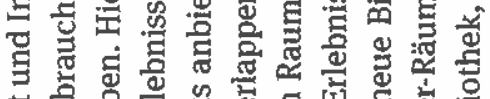

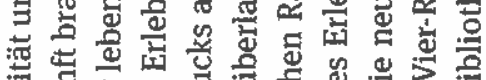

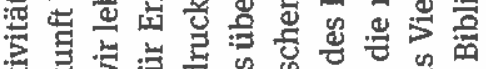

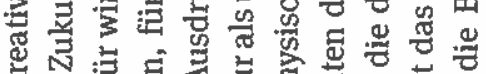

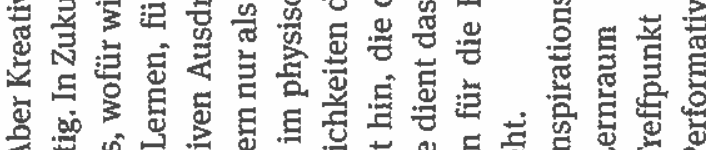

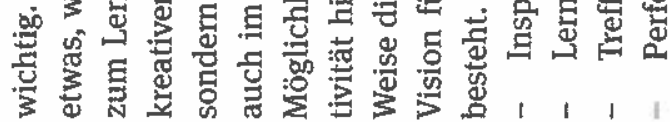

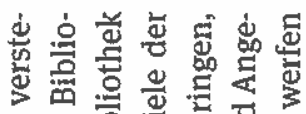

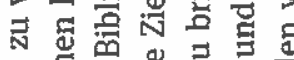

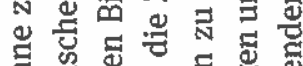

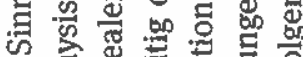

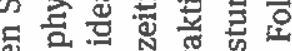

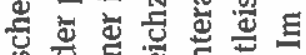

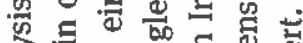

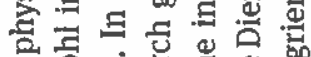

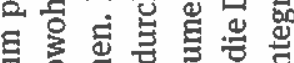

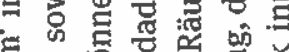

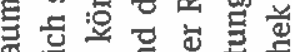

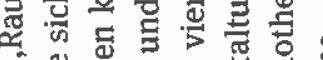

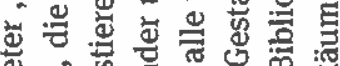

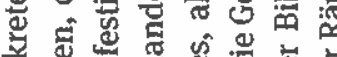

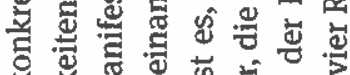
装要

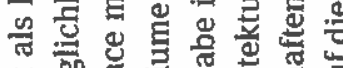

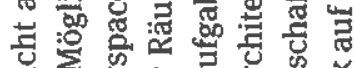

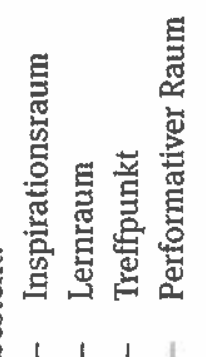

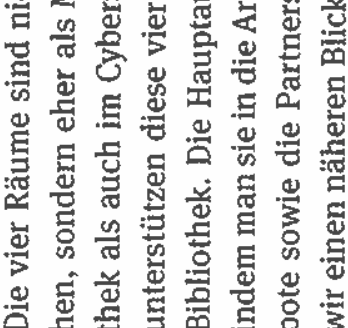

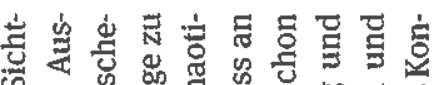

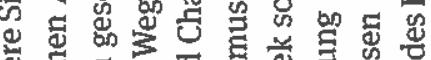

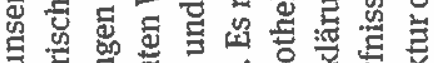

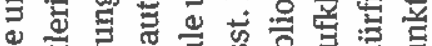

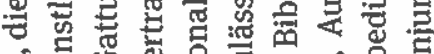

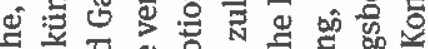

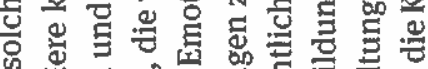

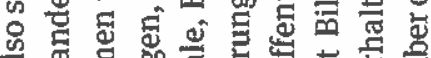

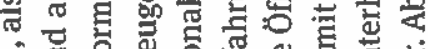

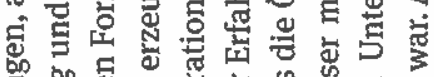

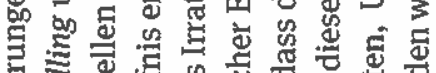

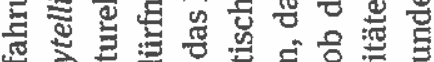

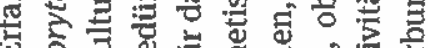

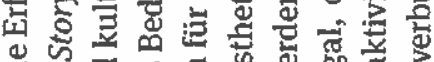

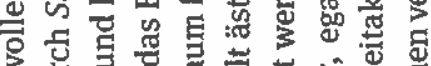

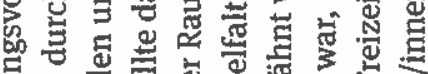

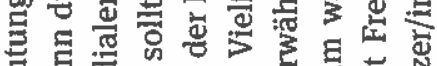

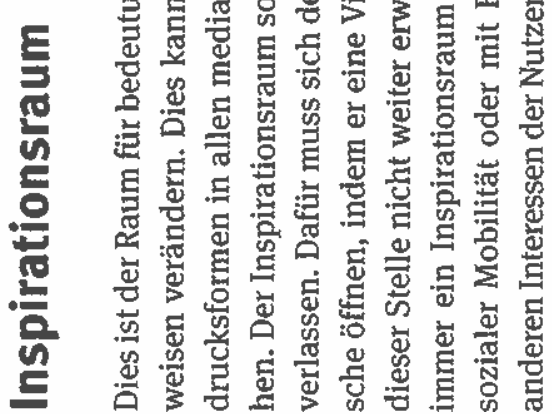

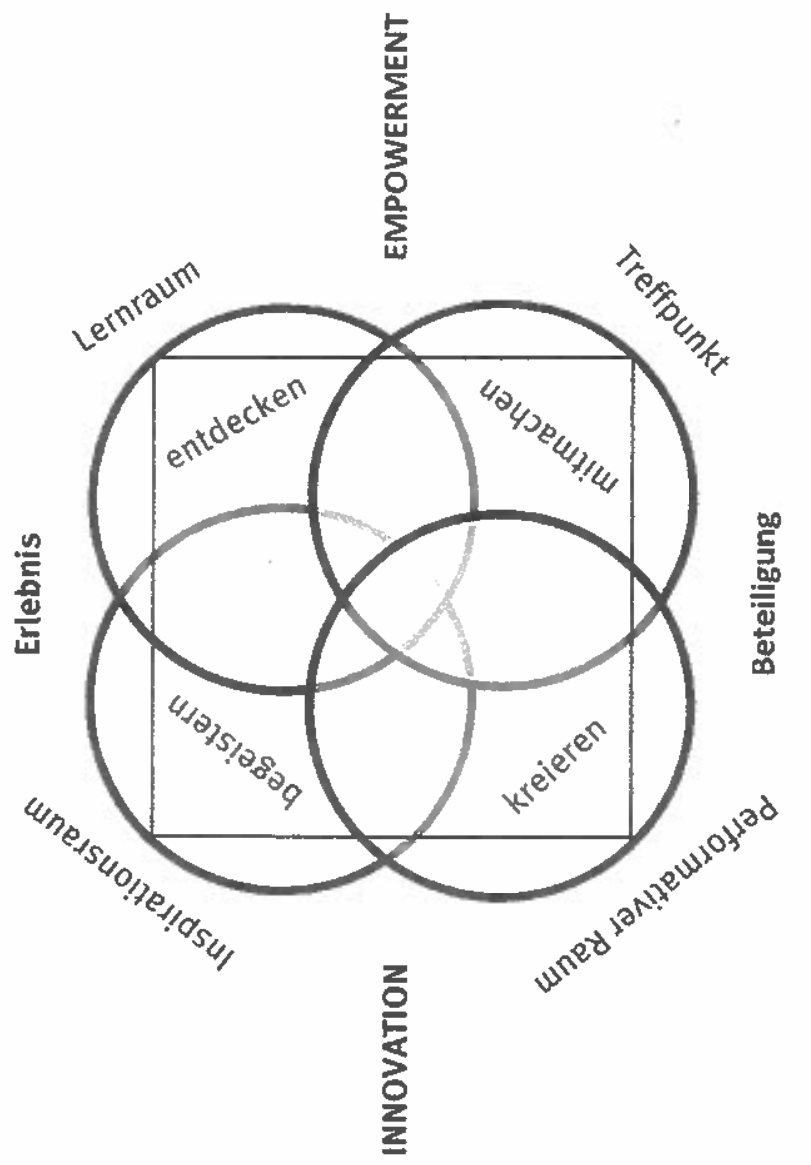

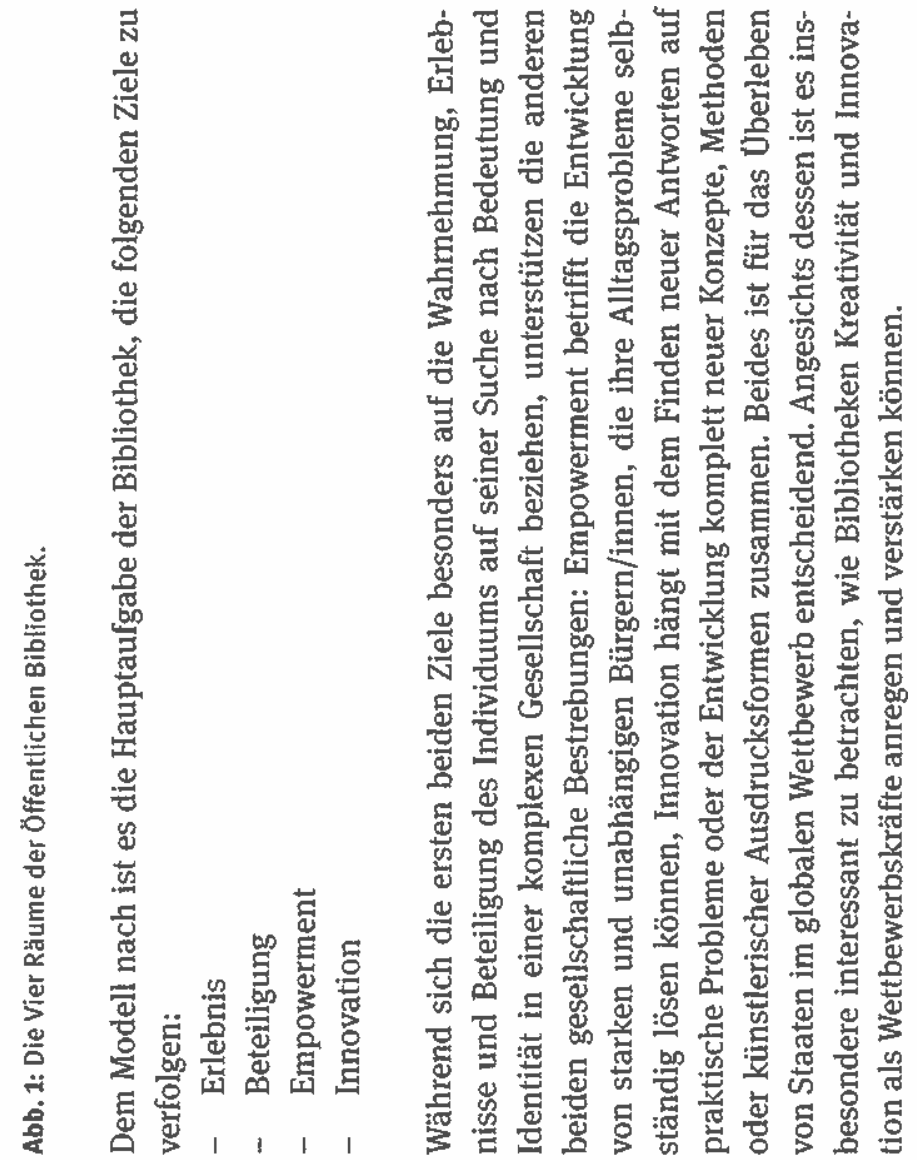




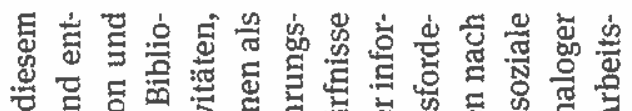

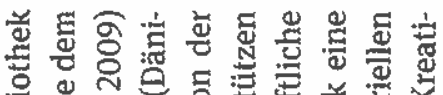

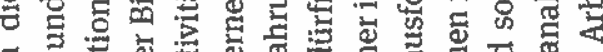

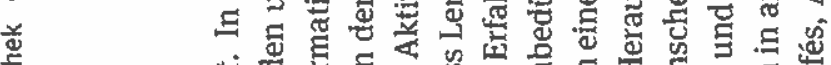

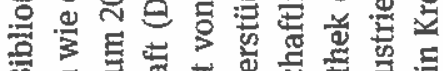

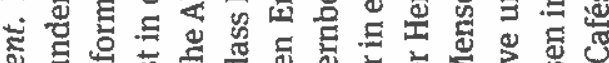

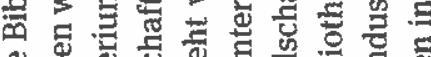

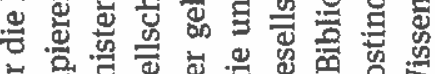

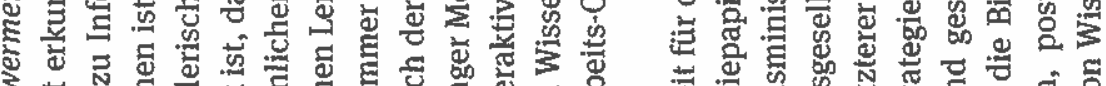

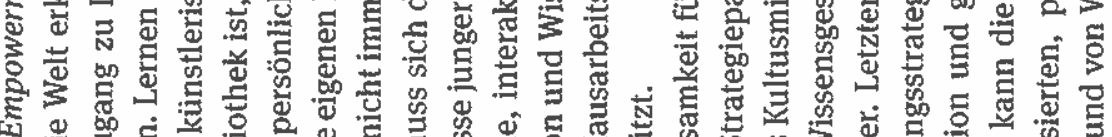

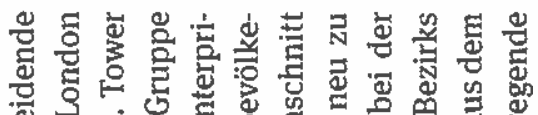

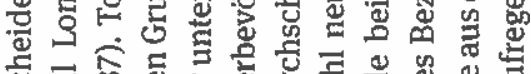

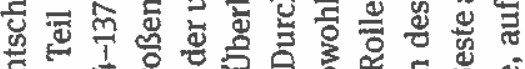

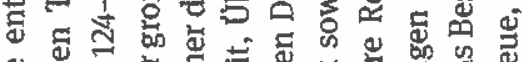

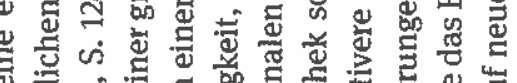

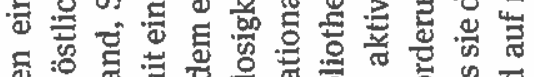

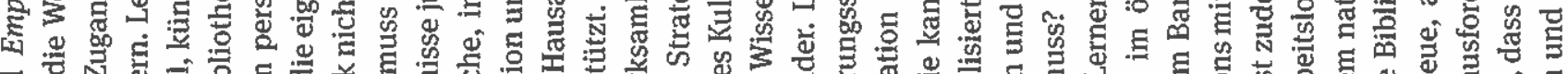

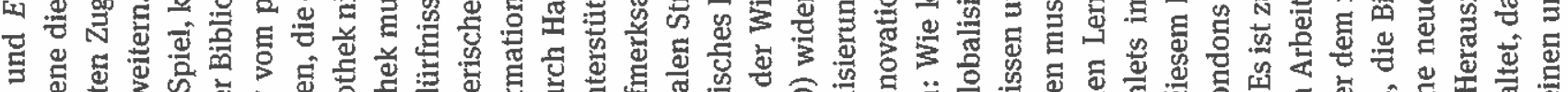

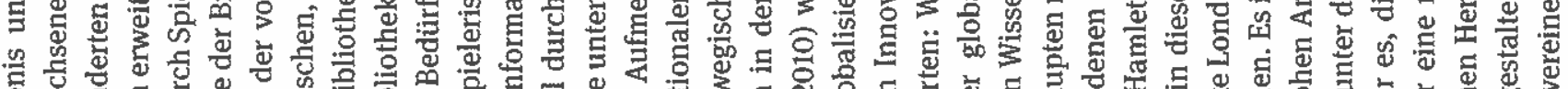

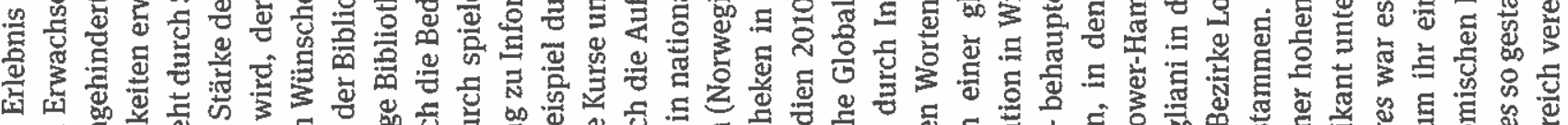

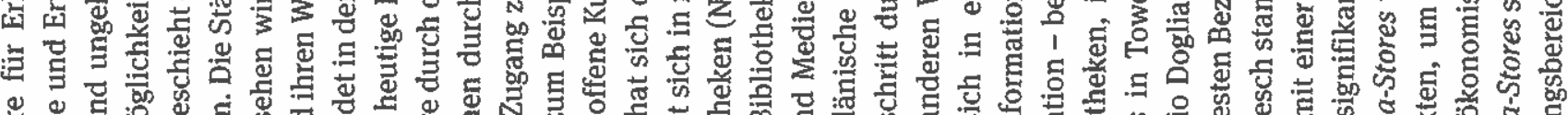

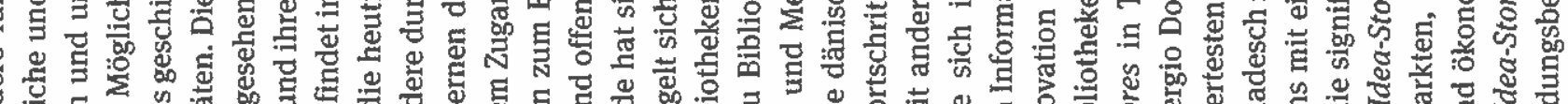

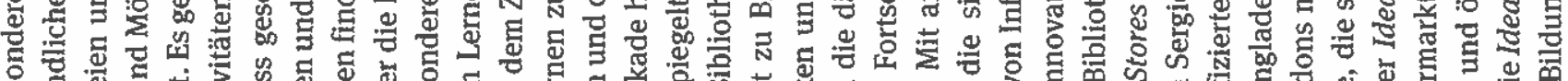

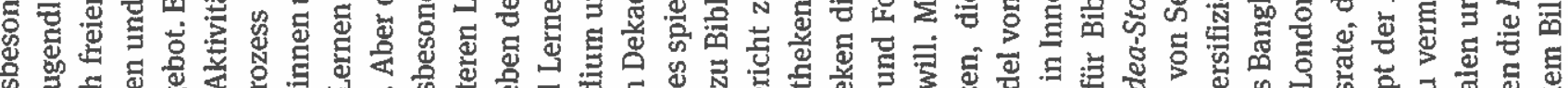

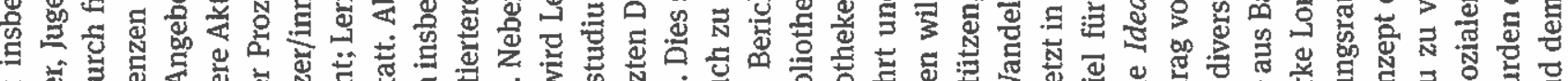

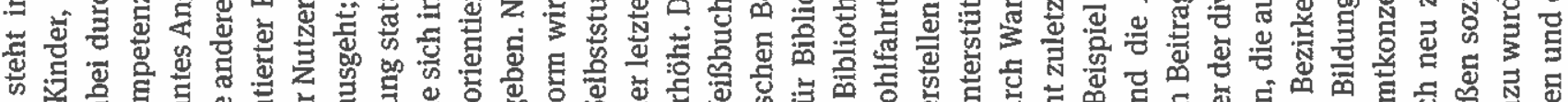

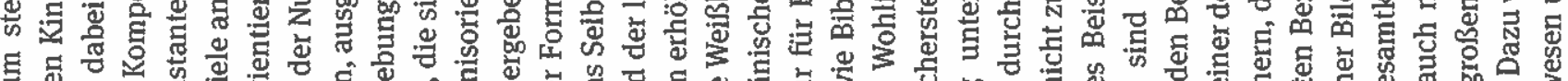

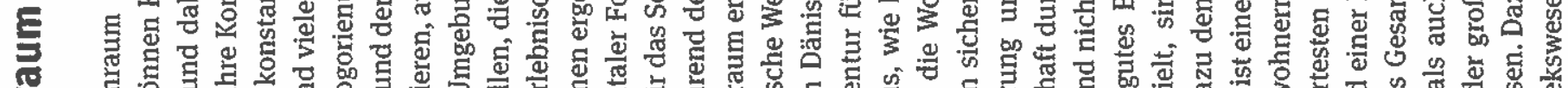

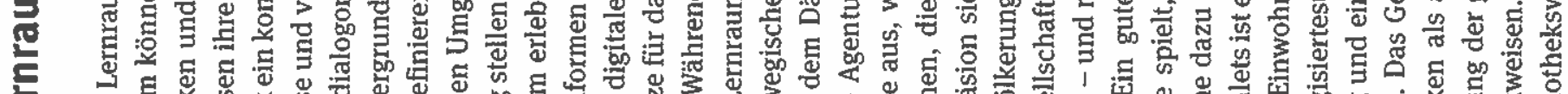

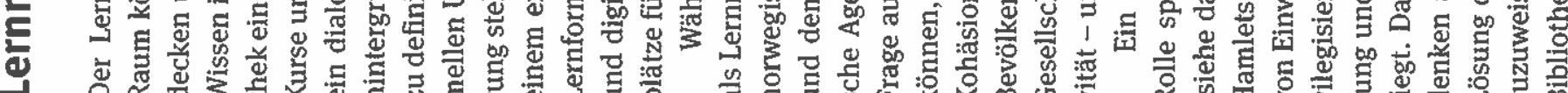

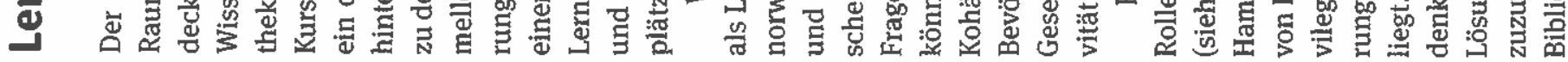

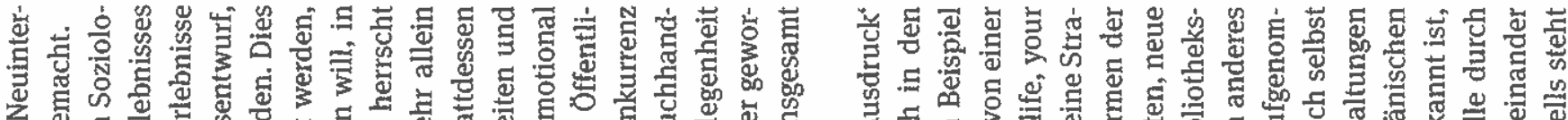

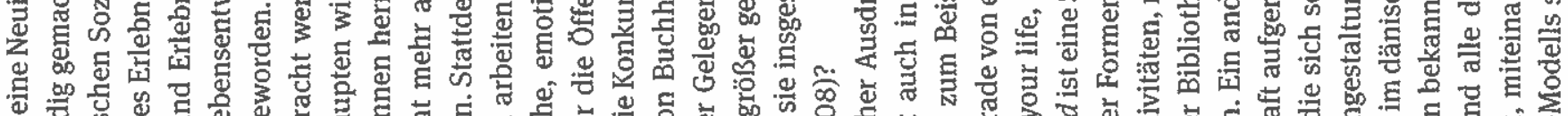

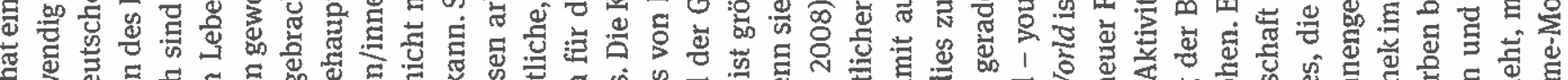

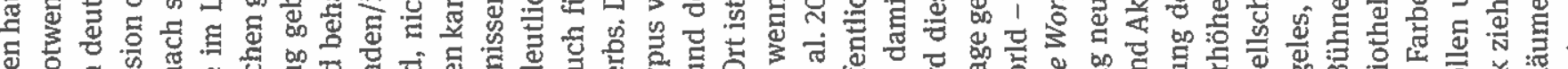

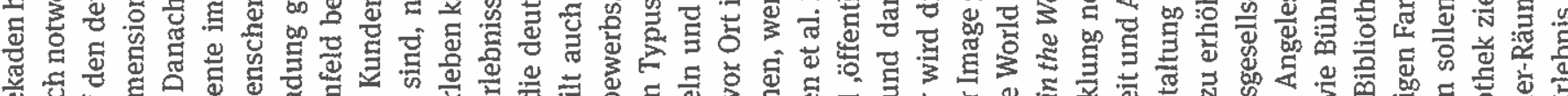

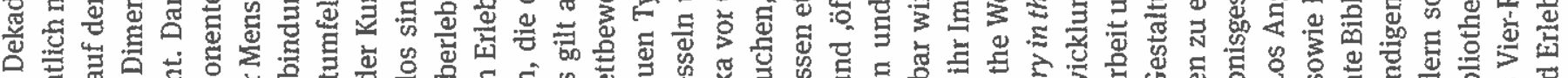

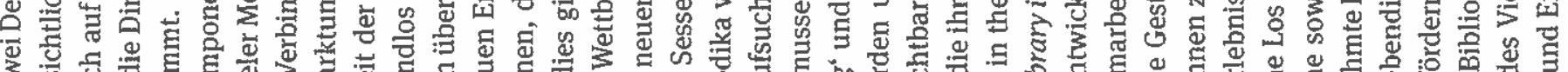

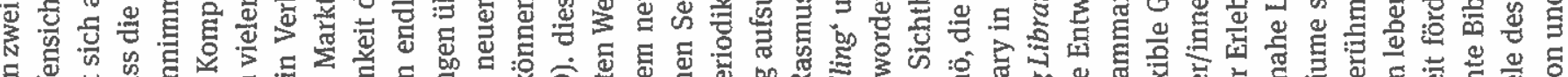

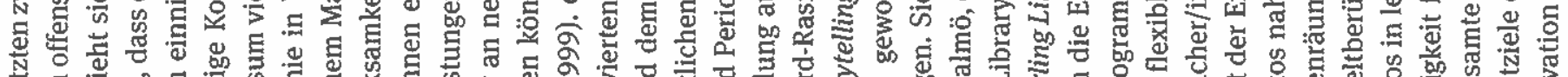

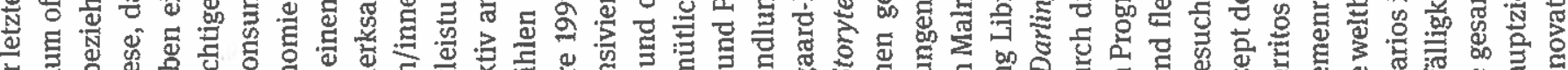

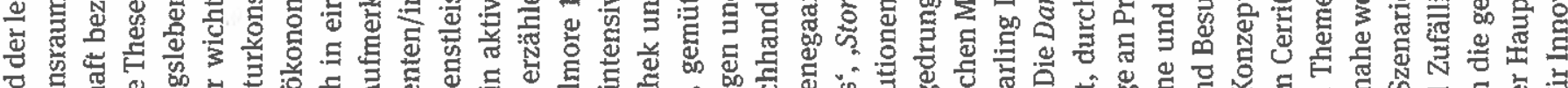

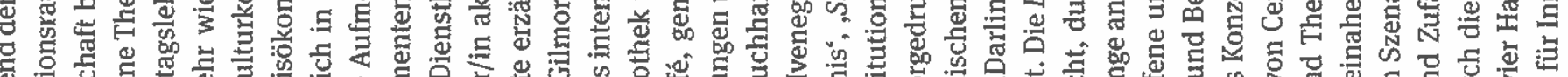

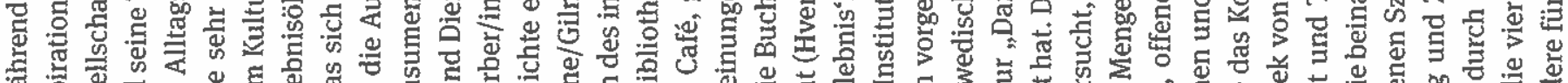

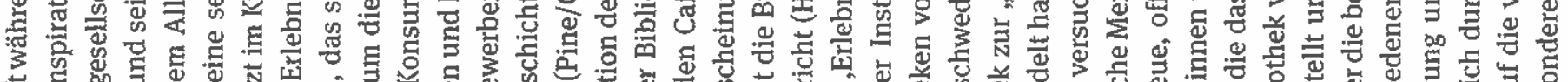

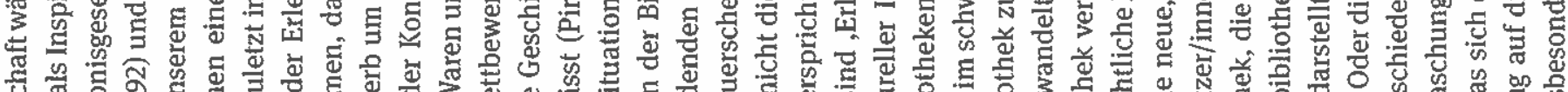

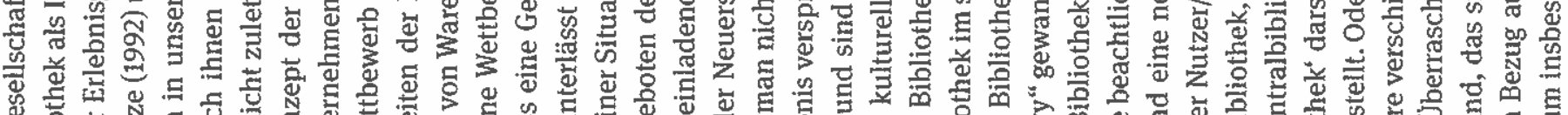

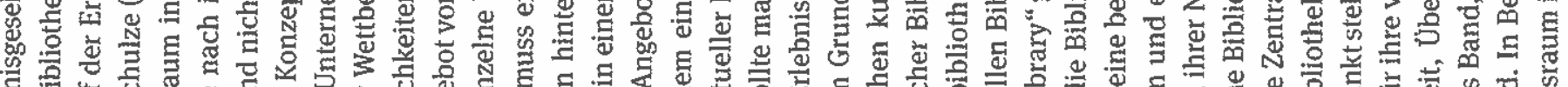

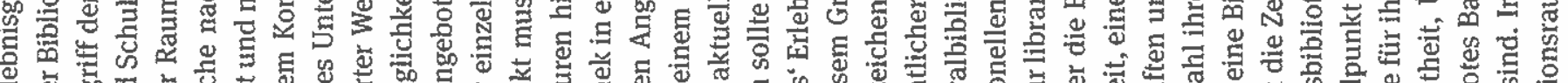

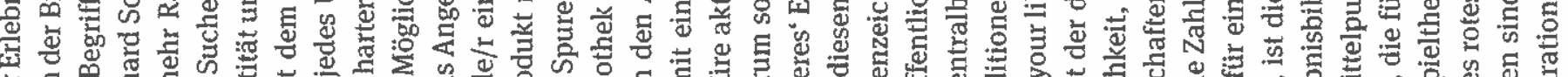

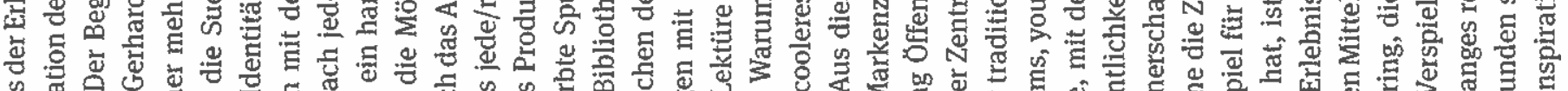

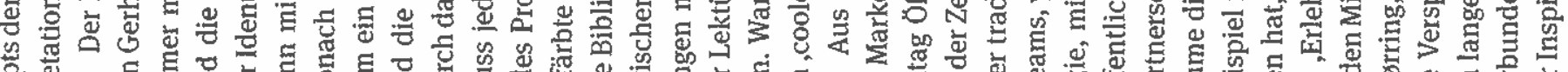

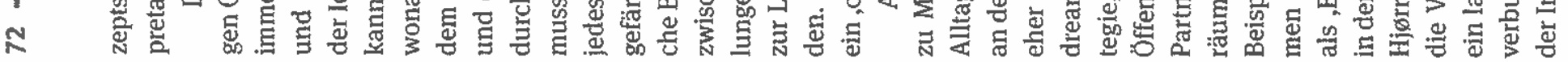




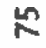

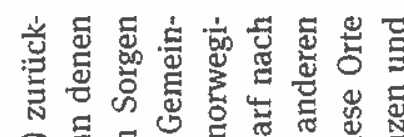

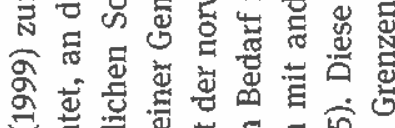

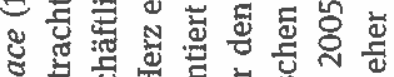

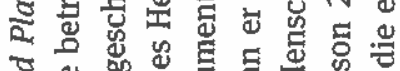

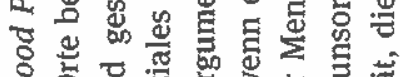

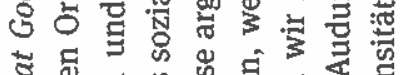

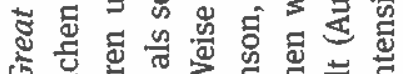

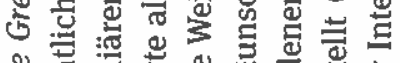

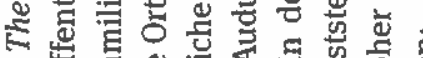

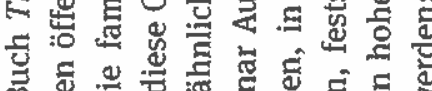

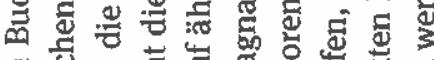

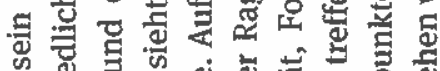

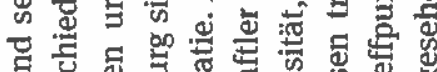

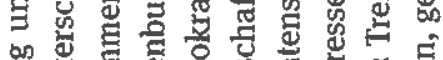

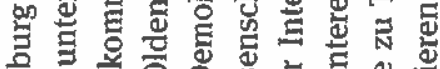

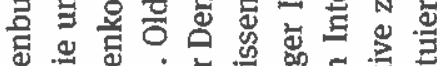

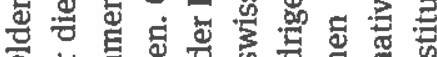

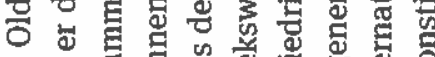

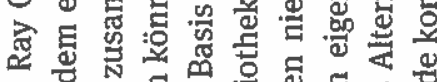

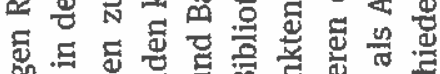

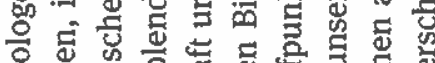

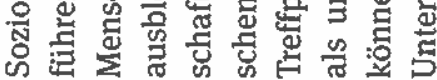

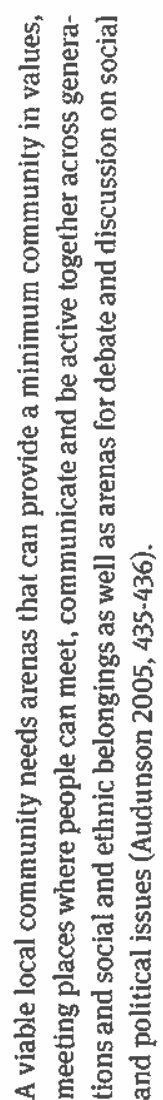

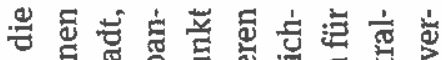

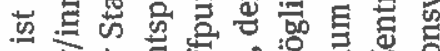

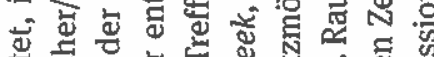

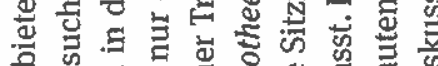

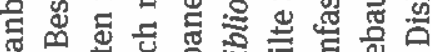

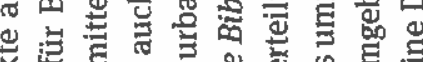
娄记

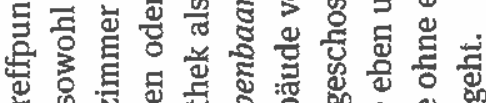

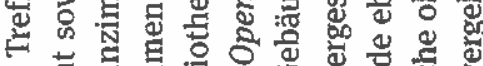
节

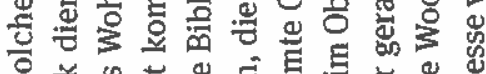

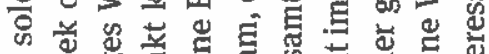

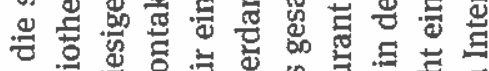

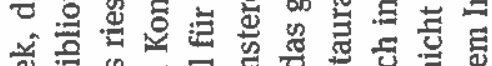

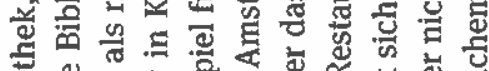

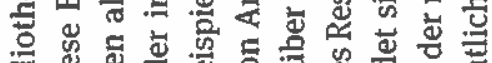

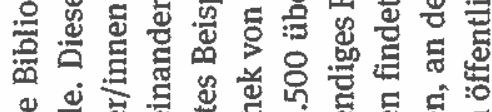

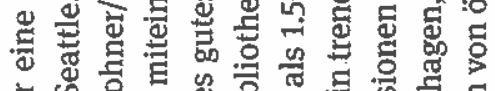
茟

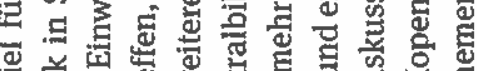

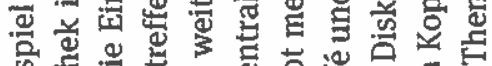

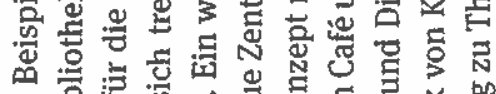

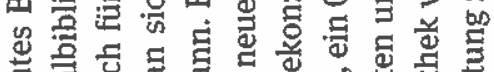

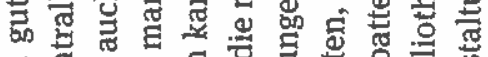

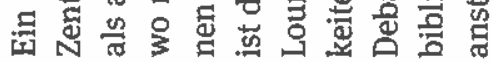

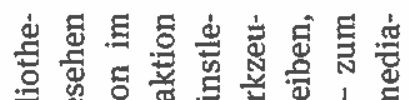
응

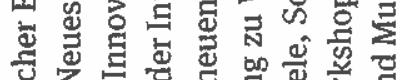

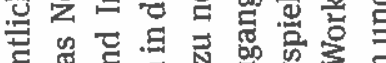

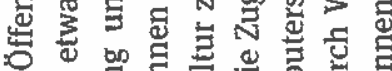

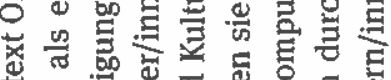

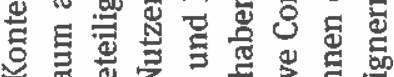

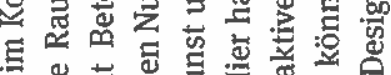

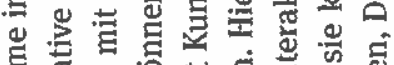

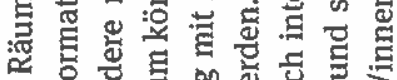

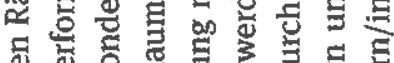

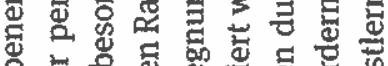

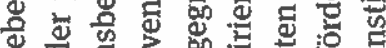

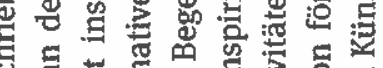

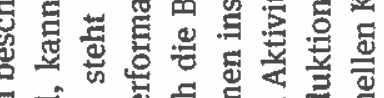
ณ

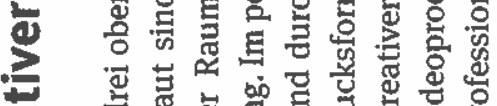

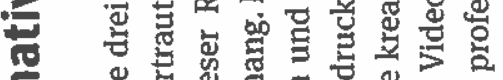

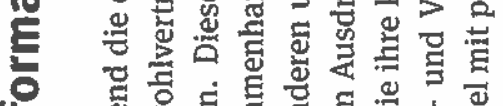

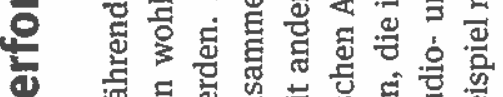

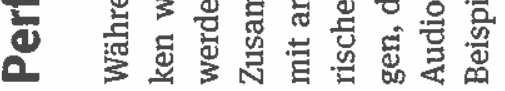

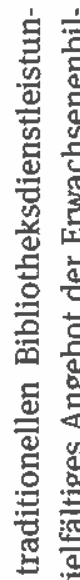

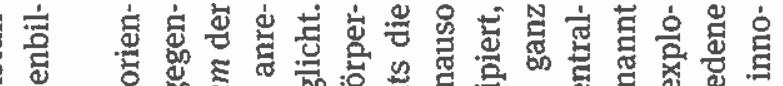

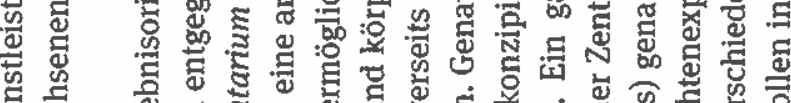

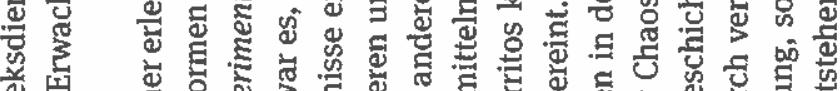

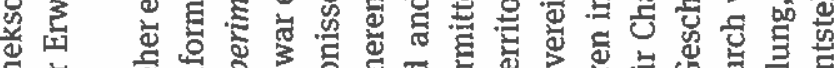

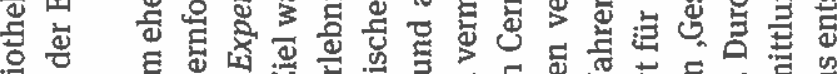

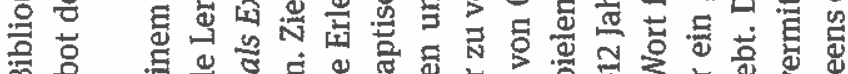

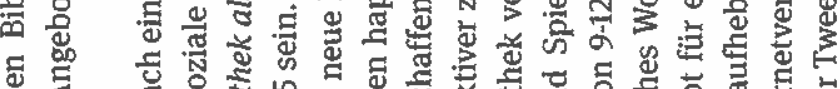

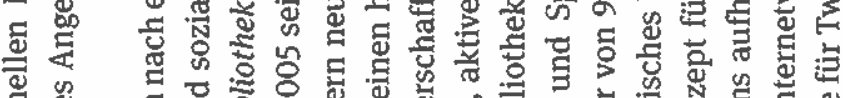

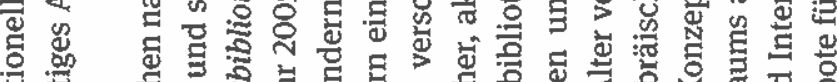

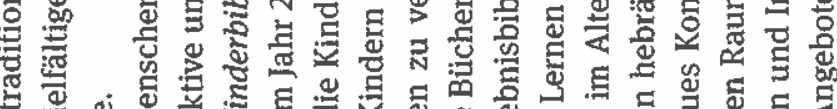

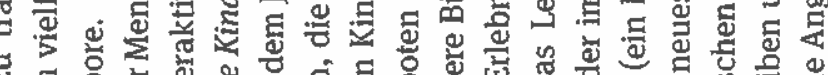

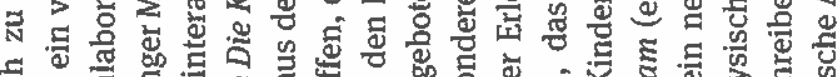

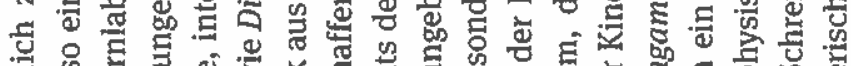

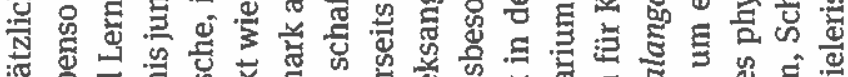

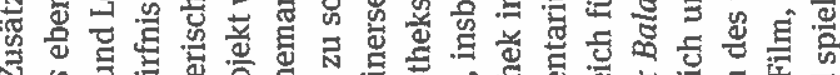

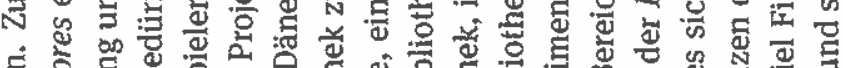

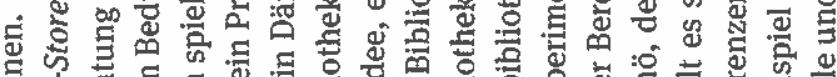

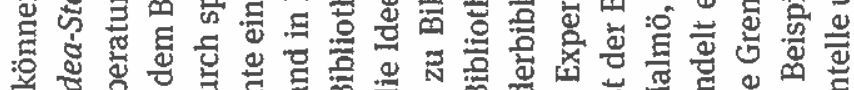

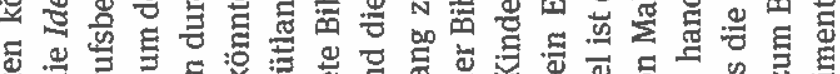

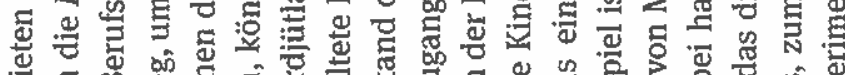

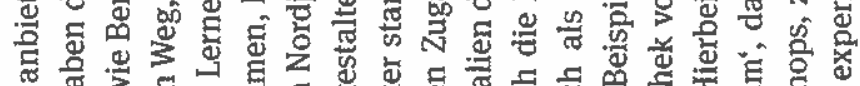

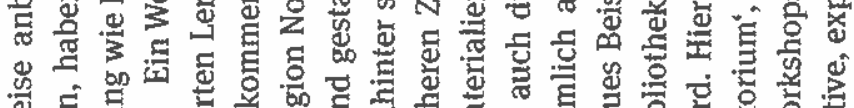

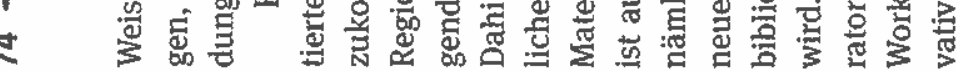

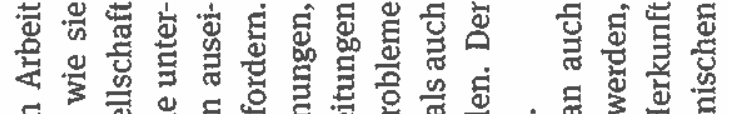

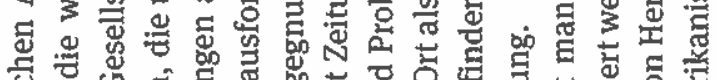

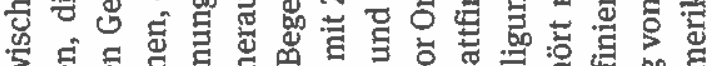

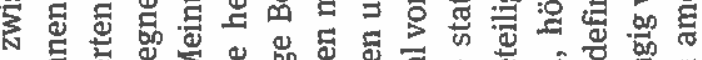

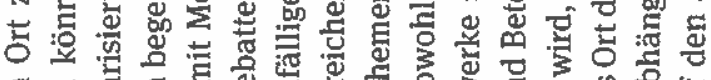

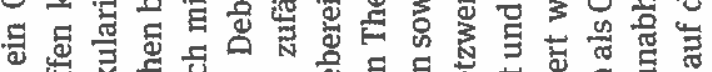

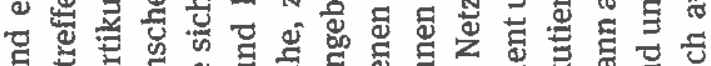

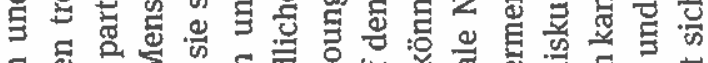

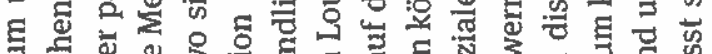

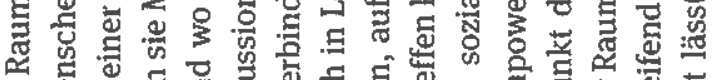

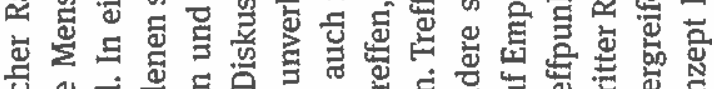

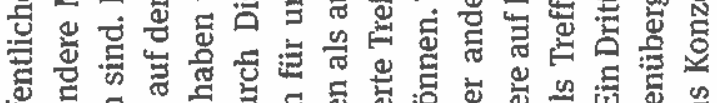

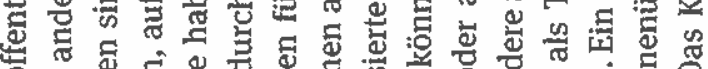

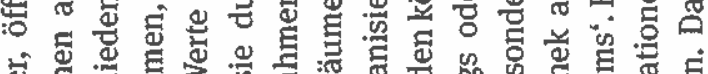

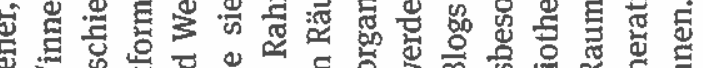

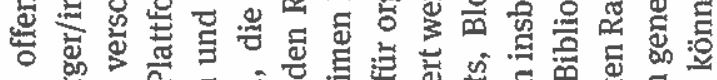

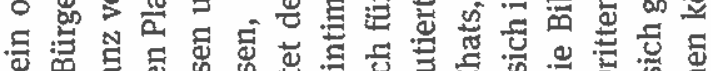

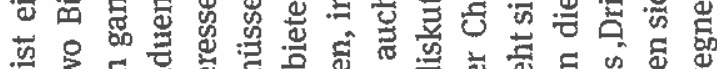

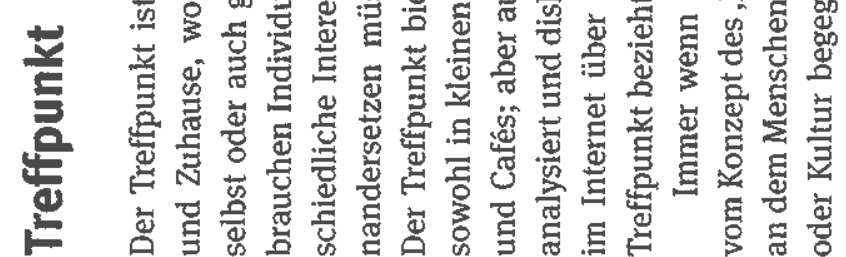




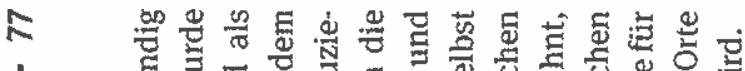

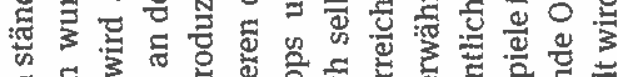

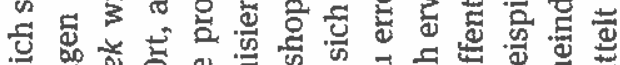
क 击 을 㟧

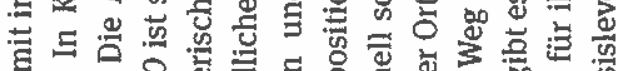
혐

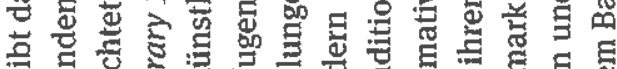

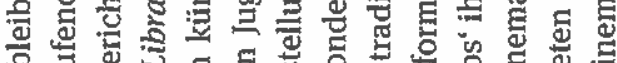

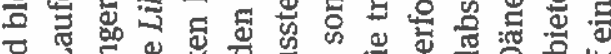

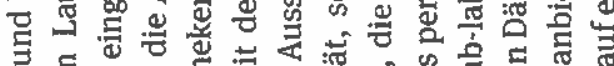

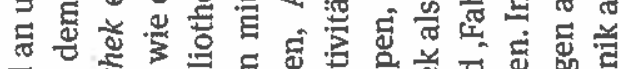

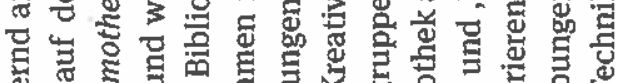

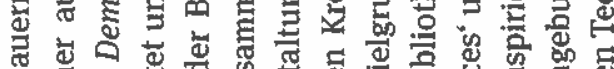

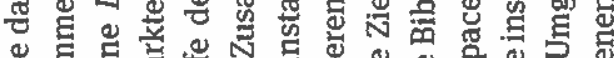
응 둥

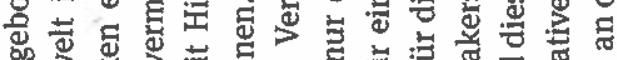

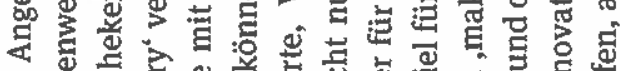

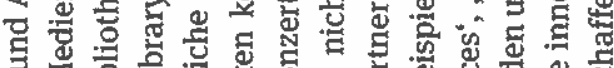

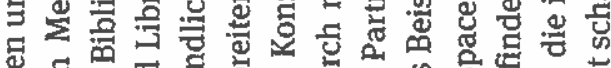

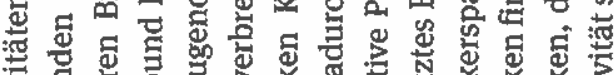

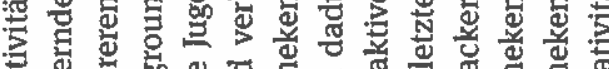

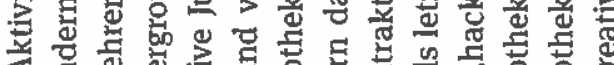

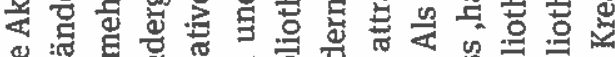

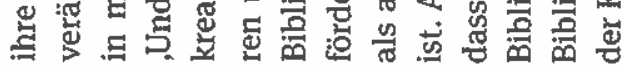

章宾 焉 를 $\sum \frac{n}{10}$ 퀄 : 变 造 3 䴦

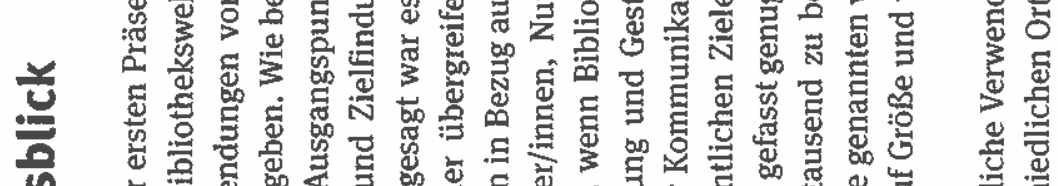

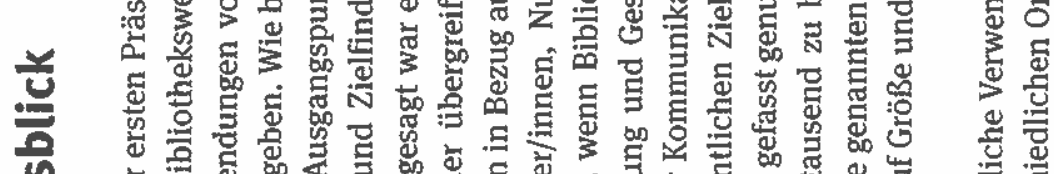

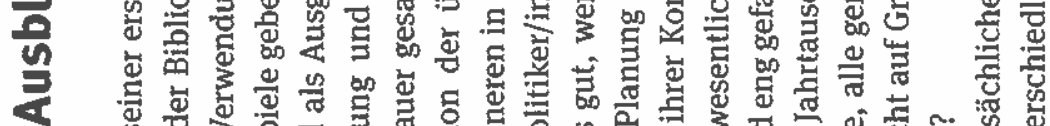
-

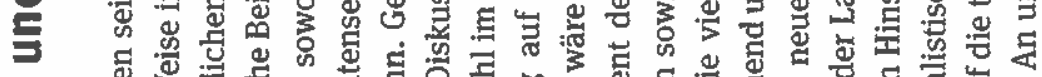

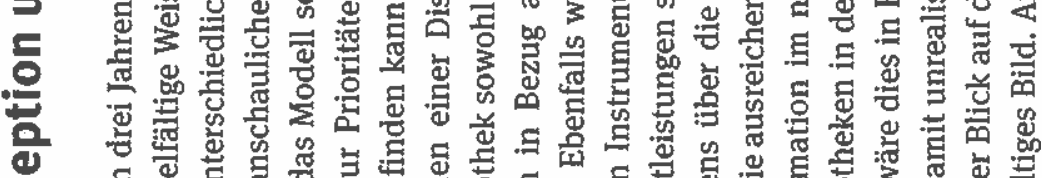

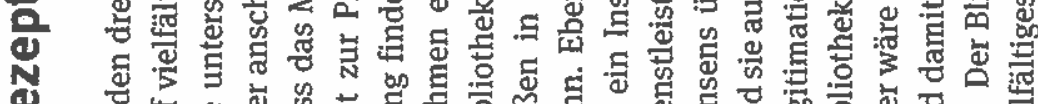
O

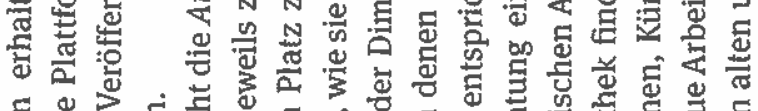

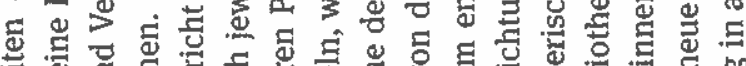

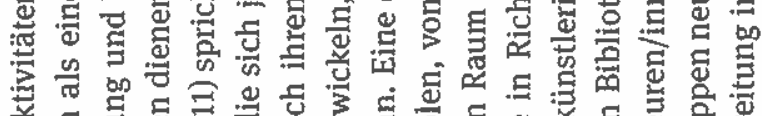

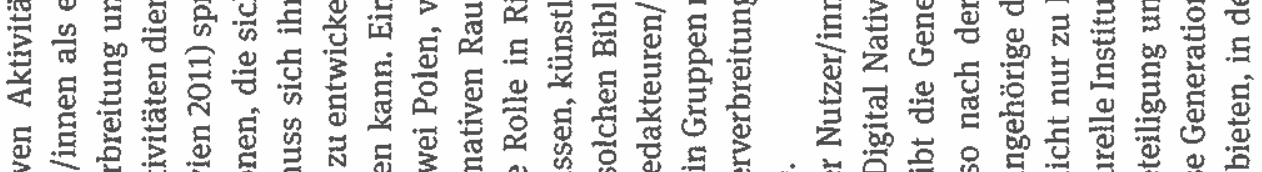

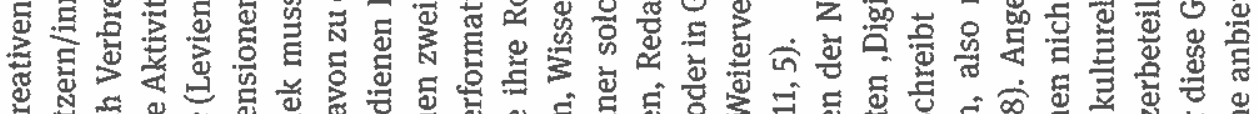

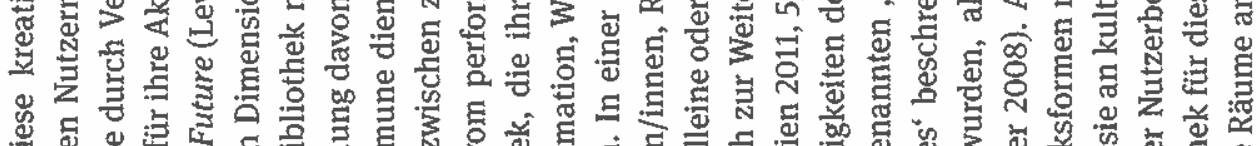

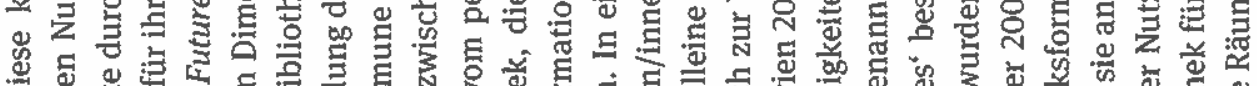

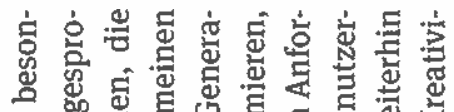

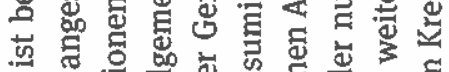

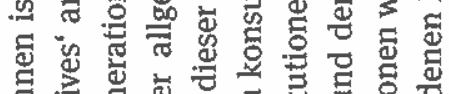

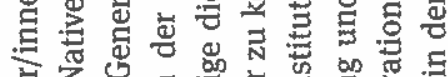

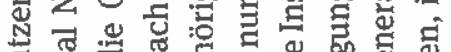

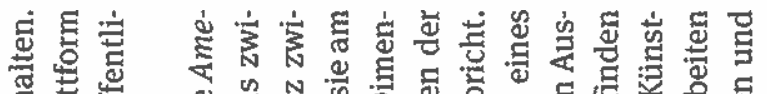

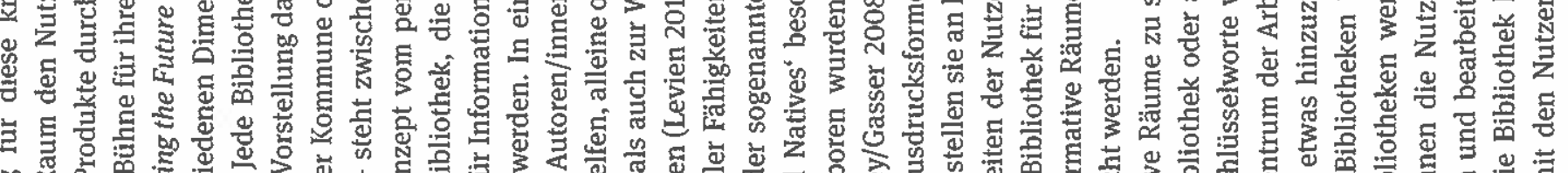

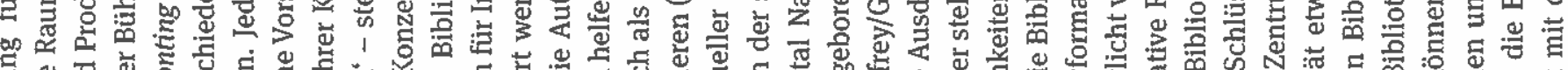

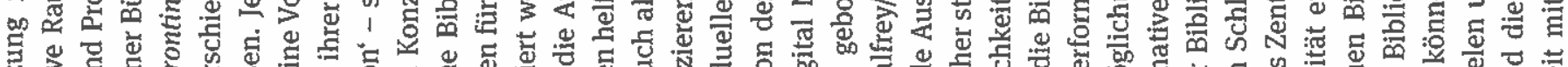

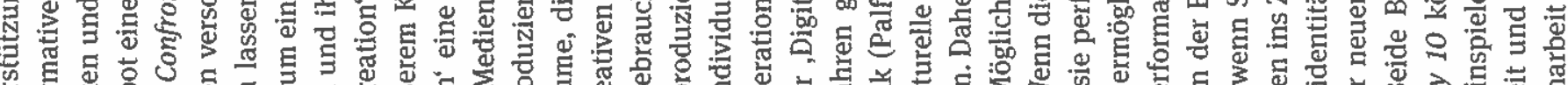

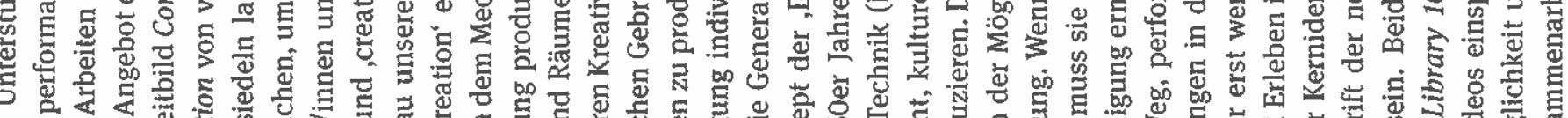

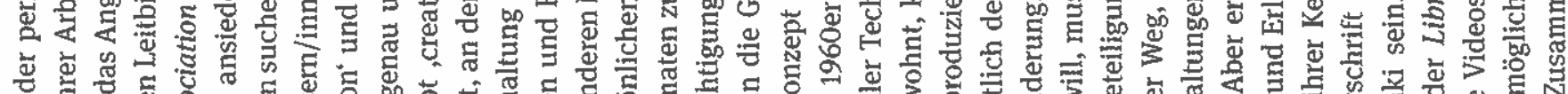

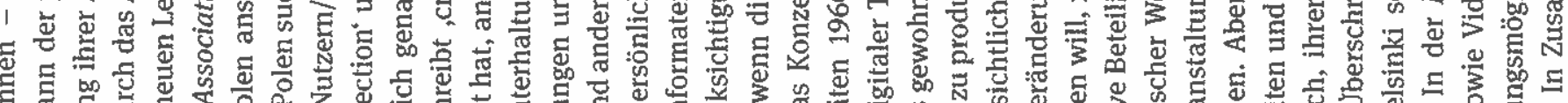

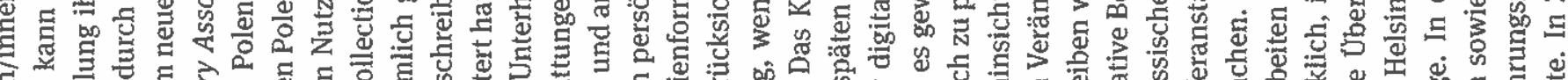

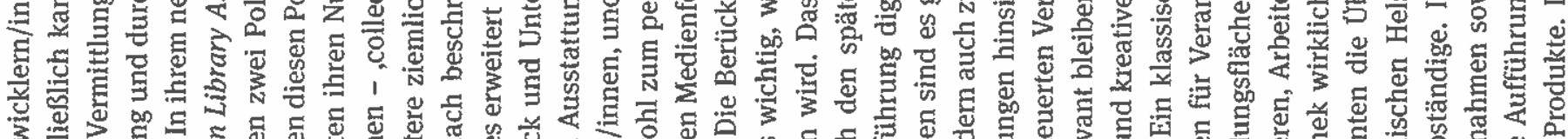

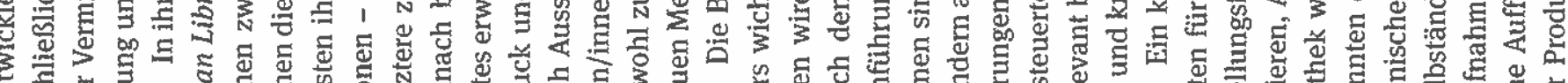

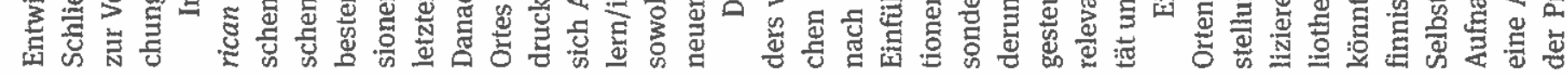

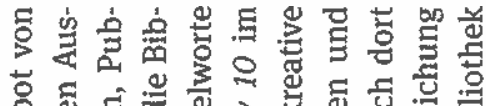

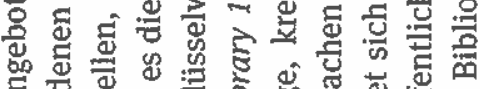

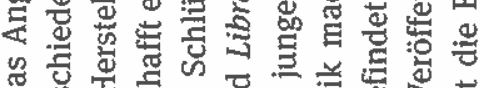

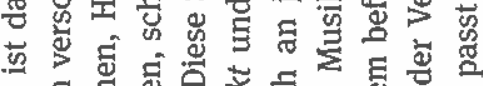

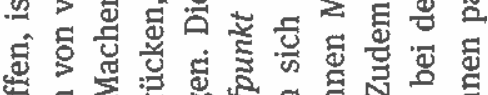

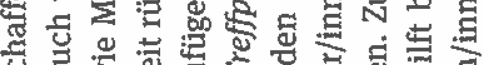

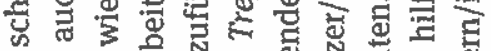

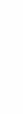

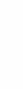




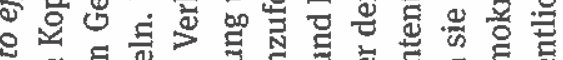

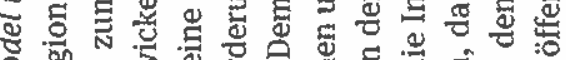

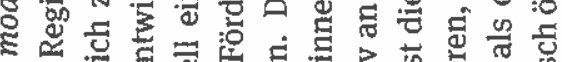

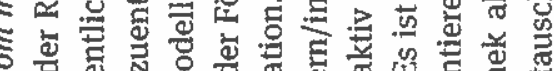
产

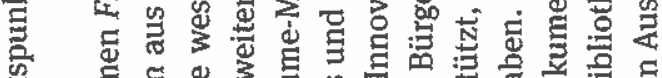

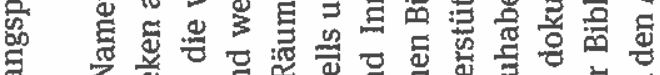

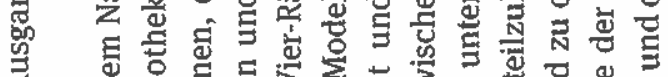

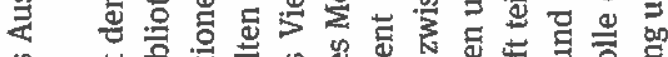

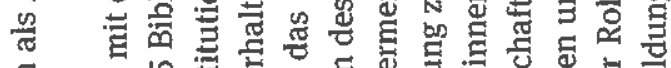

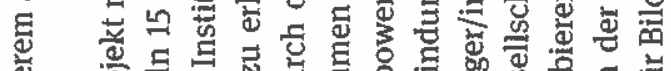

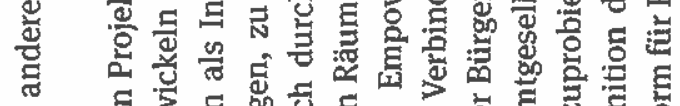

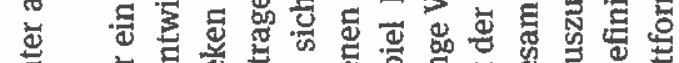

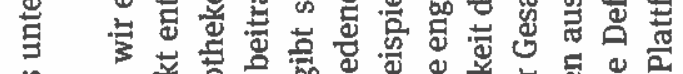

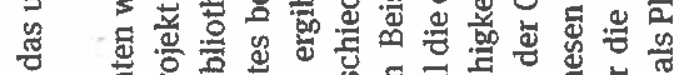

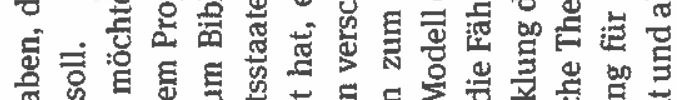

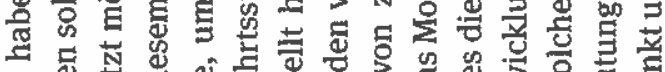

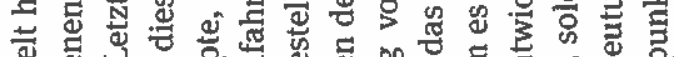

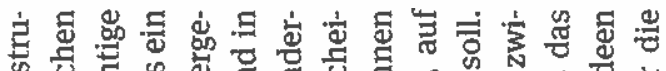

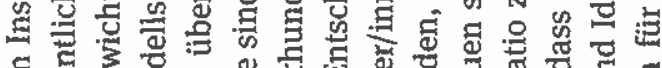

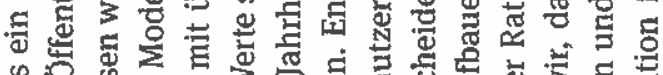

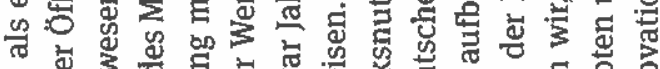

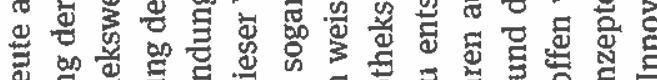

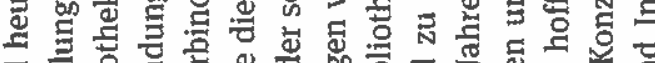

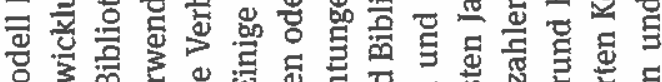

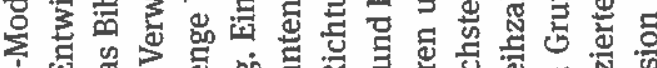

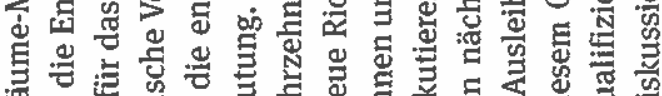

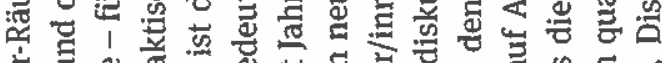

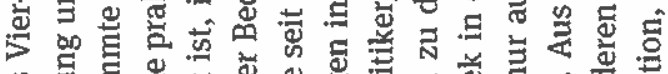

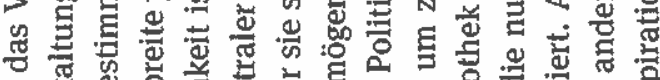

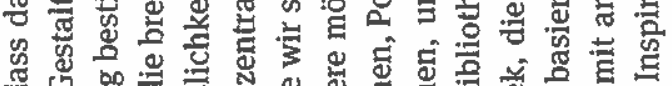

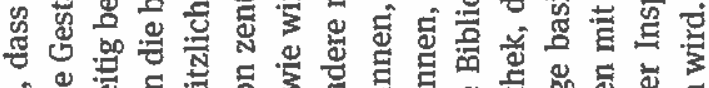

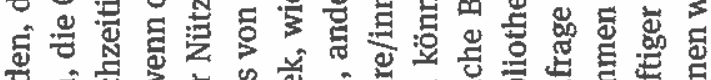

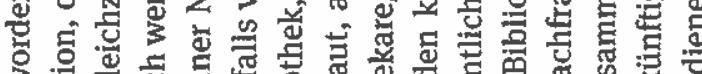

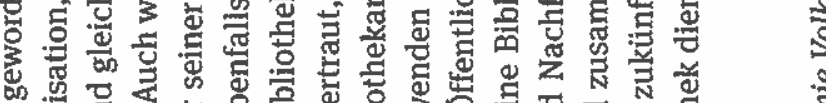

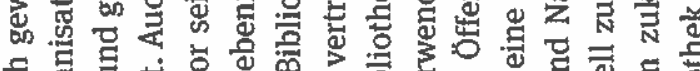

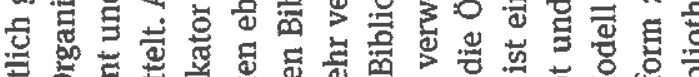

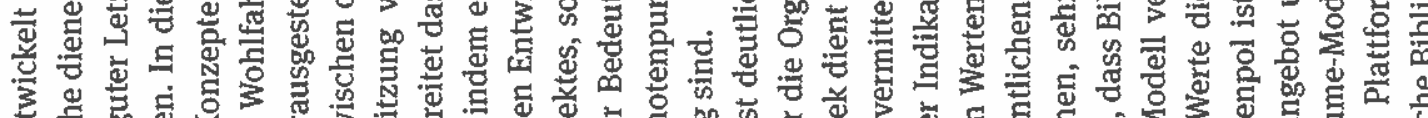

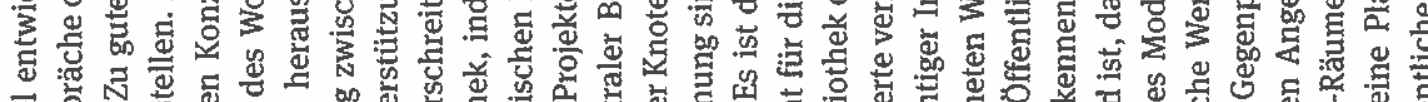

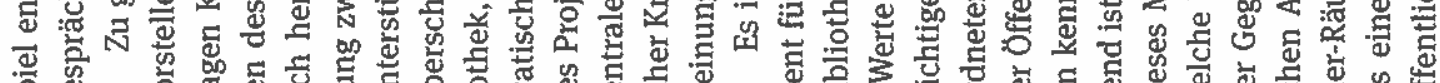

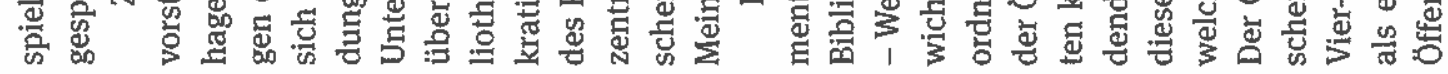

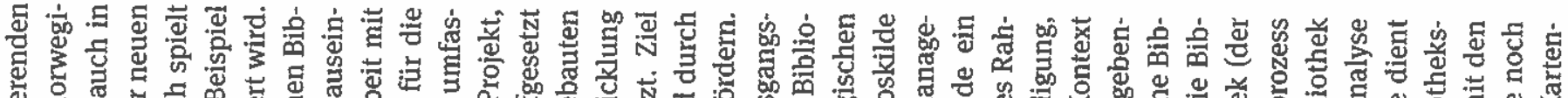

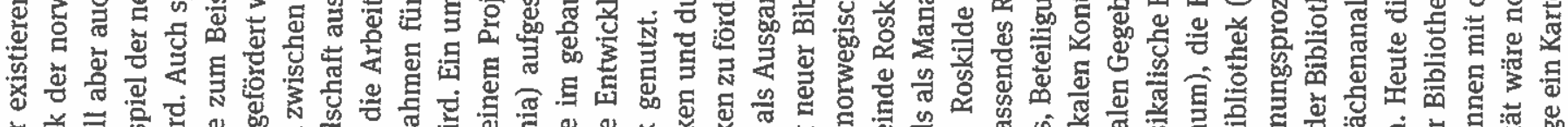

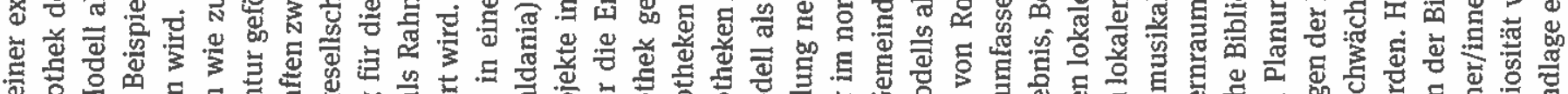

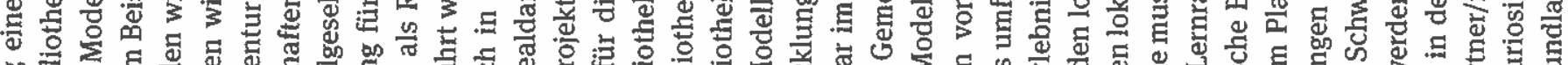

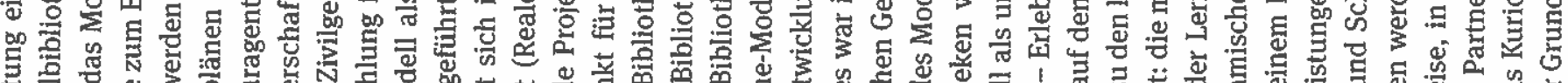

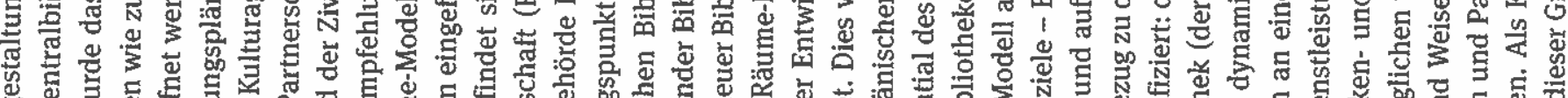

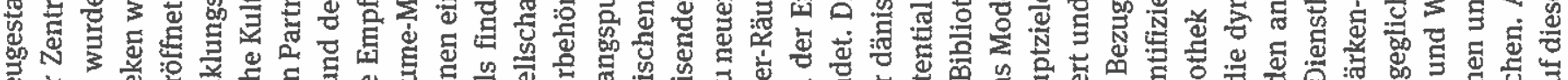

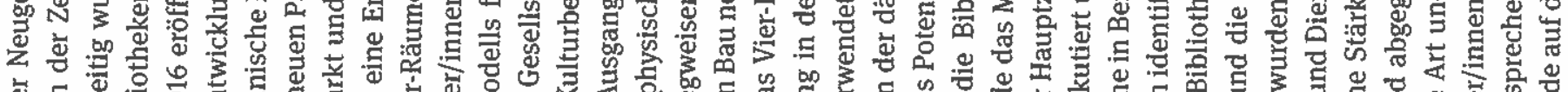

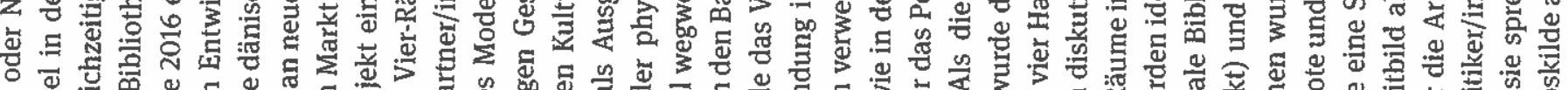

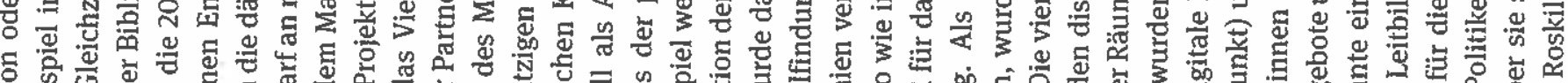

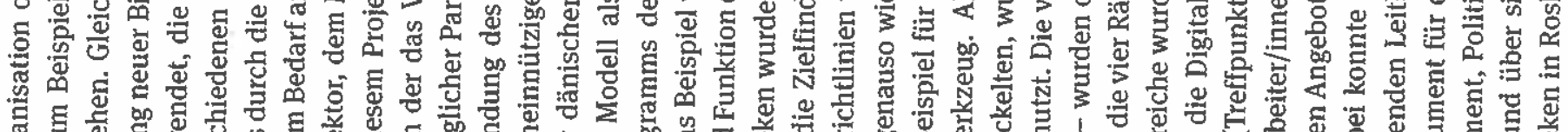

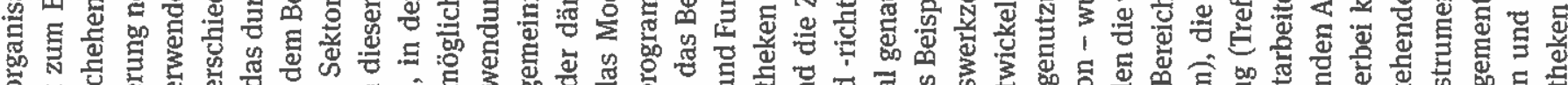

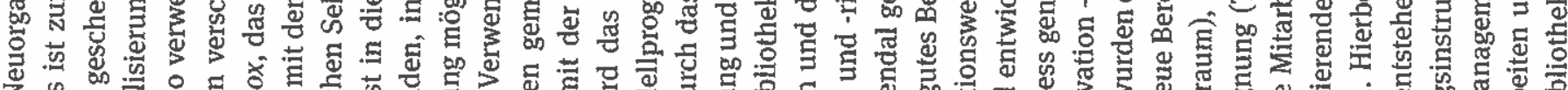

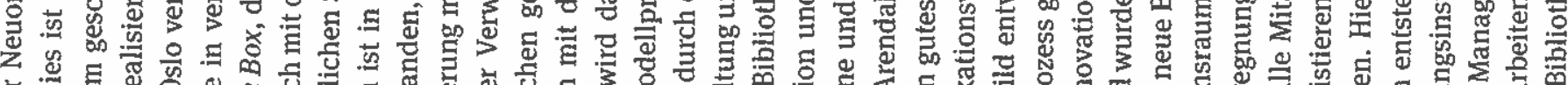

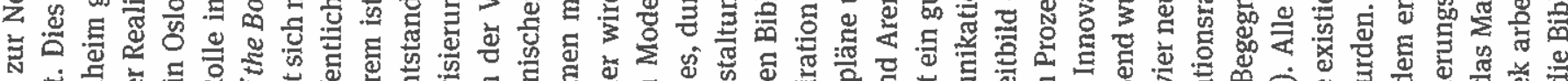

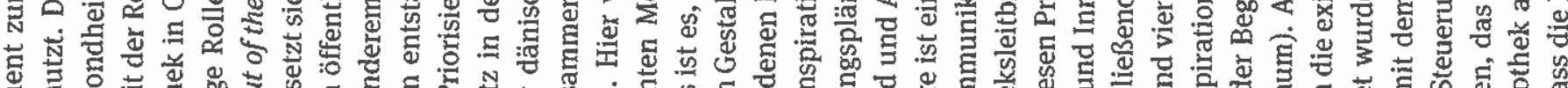

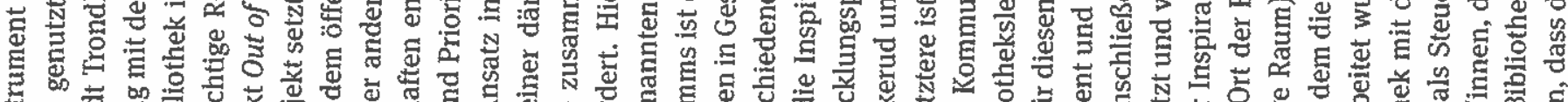

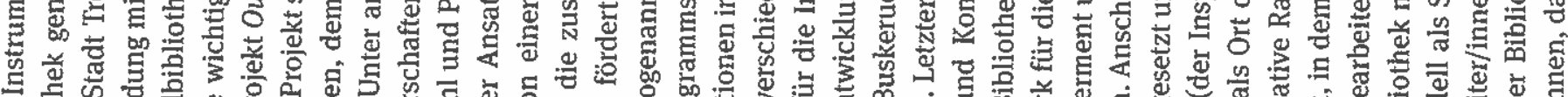

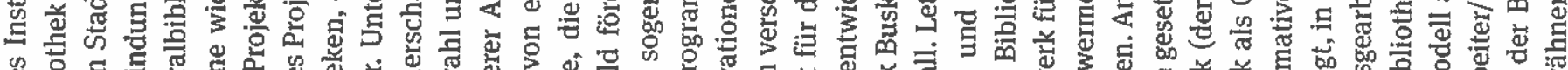

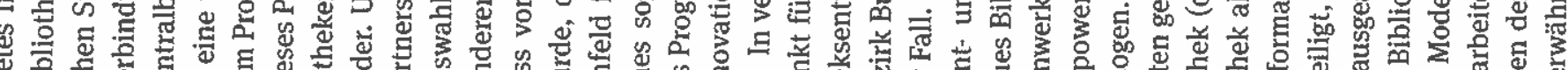

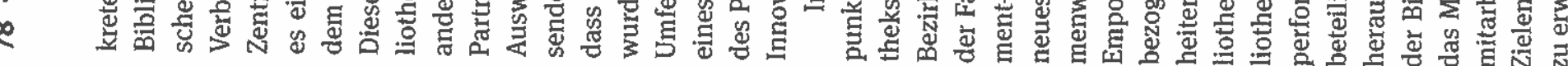

